\title{
Synthesis, Characterization and Exchange Reactions of Layered Double Hydroxides of Copper and Aluminum, Intercalated with Sulfate
}

\author{
Anne R. Sotiles, ${ }^{a}$ Marco T. Grassi, ${ }^{\circledR a}$ Mayara P. dos Santos ${ }^{a}$ and Fernando Wypych ${ }^{\circledR *, a}$ \\ ${ }^{a}$ Departamento de Química, Universidade Federal do Paraná, \\ CP 19032, 81531-980 Curitiba-PR, Brazil
}

\begin{abstract}
Layered double hydroxides (LDHs) of $\mathrm{Cu}: \mathrm{Al}$ in the molar ratio of 2:1, intercalated with sulfate, sulfate/ $\left(\mathrm{Li}^{+}, \mathrm{Na}^{+}, \mathrm{K}^{+}\right.$or $\left.\mathrm{NH}_{4}{ }^{+}\right), \mathrm{NO}_{3}{ }^{-}$and $\mathrm{CO}_{3}{ }^{2-}$, were synthesized by co-precipitation with increasing $\mathrm{pH}$. The materials were submitted to exchange reactions using $\mathrm{B}_{2} \mathrm{SO}_{4}\left(\mathrm{~B}=\mathrm{Li}^{+}, \mathrm{Na}^{+}, \mathrm{K}^{+}\right.$, $\mathrm{NH}_{4}^{+}$) solutions in an attempt to replace previously intercalated cations or incorporated cations without removing intercalated sulfate. X-ray diffraction (XRD) patterns and Fourier transform infrared (FTIR) spectra were consistent with the expected intercalated species and scanning electron microscopy (SEM) images indicated submicrometric platelet-like particles, typical of LDHs. The chemical compositions of all phases were confirmed by inductively coupled plasma optical emission spectrometry (ICP OES) and thermogravimetric analyses (TGA). In the exchange reactions, only in $\left[\mathrm{Cu}_{6} \mathrm{Al}_{3}(\mathrm{OH})_{18}\right]\left[\mathrm{Na}\left(\mathrm{H}_{2} \mathrm{O}\right)_{6}\left(\mathrm{SO}_{4}\right)_{2}\right] \cdot 6 \mathrm{H}_{2} \mathrm{O}$ the sodium cations were almost totally replaced with lithium, potassium and ammonium, without removing the intercalated sulfate.
\end{abstract}

Keywords: layered double hydroxide, sulfate, exchange reaction, copper, aluminum

\section{Introduction}

Layered double hydroxides (LDHs) are a class of materials belonging to the hydrotalcite-like compounds. These compounds have brucite-like structure $\left(\mathrm{Mg}(\mathrm{OH})_{2}\right)$, where each metallic cation occupies the center of an octahedron whose vertices contain hydroxide anions. The octahedra share edges to form two-dimensional layers, which are stacked along the basal axis. However, in the case of LDHs, part of the $\mathrm{M}^{2+}$ cations are replaced by $\mathrm{M}^{3+}$ cations, generating an excess of positive charges on the layer. This excess of positive charges is compensated by the insertion of anions in the space between layers. ${ }^{1-4}$

LDHs are represented by the general composition $\left[\mathrm{M}^{2+}{ }_{1-\mathrm{x}} \mathrm{M}^{3+}{ }_{\mathrm{x}}(\mathrm{OH})_{2}\right]\left(\mathrm{A}^{\mathrm{n}-}\right)_{\mathrm{x} / \mathrm{n}} \cdot \mathrm{yH}_{2} \mathrm{O}$, where $\mathrm{M}^{2+}$ and $\mathrm{M}^{3+}$ are divalent and trivalent metal cations and $\mathrm{A}^{\mathrm{n}-}$ denotes intercalated anhydrous or hydrated anions with charge $n-.^{5-7}$ Several combinations between $\mathrm{M}^{2+}$ and $\mathrm{M}^{3+}$ with different intercalated anions have been studied, and new phases are being synthesized and evaluated regarding the formation of compounds, their properties and applications. ${ }^{8-12}$

Due to the presence of positively charged layers, these compounds are well known for their anion exchange capacity. However, it has recently been reported ${ }^{13}$ that

*e-mail: wypych@ufpr.br some LDHs have the ability to intercalate cations and anions and exchange both simultaneously or separately. Among the anions studied, sulfate has been gaining prominence, mainly because $\mathrm{LDHs}$ are similar to the minerals motukoreaite $(\mathrm{Mg} / \mathrm{Al})$, natroglaucocerinite $(\mathrm{Zn} / \mathrm{Al})$ and shigaite $(\mathrm{Mn} / \mathrm{Al}),{ }^{14-16}$ in addition to other phases containing $\mathrm{Co} / \mathrm{Al}$ and $\mathrm{Ni} / \mathrm{Al} .{ }^{17}$ These have been synthesized with sulfate, and intercalation of alkali metal cations such as lithium, sodium and potassium has been observed..$^{13,17}$

In recent years, layered compounds have received great attention due to their wide applications, such as protection against UV radiation in polymers ${ }^{18}$ emulsion stabilization, ${ }^{19}$ catalysis, ${ }^{20,21}$ adsorption, ${ }^{22}$ degradation of dyes and organic compounds, ${ }^{23,24}$ drug release, ${ }^{25-27}$ UV-radiation polymer protection ${ }^{28}$ and flame retardance..$^{29}$ Since LDHs are materials obtained at relatively low cost, it is attractive to increase the study of these compounds, including synthesizing new phases that can have diversified properties for diverse applications. An element not often analyzed in structures of layered compounds and that can be further explored is copper. Most of the studies ${ }^{30-37}$ that exist involve the characterization of minerals obtained in nature.

The general information in the literature ${ }^{5,38,39}$ indicates that the proposed compositions investigated in the present article are unlikely to be obtained due especially to: (i) the precipitation of the isolated hydroxides like 
$\mathrm{Cu}(\mathrm{OH})_{2}$ and $\mathrm{Al}(\mathrm{OH})_{3}$ in the $\mathrm{pH}$ lower (ca. 5.0) than those used to precipitate the respective $\mathrm{LDH}(\mathrm{pH}$ above 7); (ii) to the Jahn-Teller effect observed with $\mathrm{Cu}^{2+}$ when hexacoordinated with hydroxide anions, leading to poor long-range ordering of the octahedral and hindering the LDH structure formation; (iii) to the Jahn-Teller effect $\mathrm{Cu}^{2+}$ site distortion, weakening the electrostatic interactions between the positively charged layers and hydrated intercalated anions; (iv) that $\mathrm{LDH}$ containing $\mathrm{Cu}^{2+}$ will only be obtained when a third $\mathrm{M}^{2+}$ metal is used in higher concentration together with $\mathrm{Cu}^{2+}$ forming ternary $\mathrm{LDH}$, which would overpass the Jahn-Teller effect, by diluting the $\mathrm{Cu}^{2+}$ in the brucite-like structure.

In spite of these discouraging effects we decided to investigate the $\mathrm{Cu}_{2} \mathrm{Al}-\mathrm{SO}_{4} \mathrm{LDH}$ system in an attempt to expand the knowledge of this class of compound. The main incentives were the scarce literature about the intercalation of sulfate in these phases and the information that $\mathrm{Cu} / \mathrm{Al} \mathrm{LDHs}$ are potential catalysts or catalysts precursors for application in different reactions (e.g., in photocatalysis, oxidation, hydrogenation, dehydration, isomerization, steam reforming, conversion of biomass, etc.). ${ }^{40-42}$

\section{Experimental}

LDHs with $\mathrm{Cu}^{2+}: \mathrm{Al}^{3+}$ molar ratios of $2: 1$ were synthesized by coprecipitation with increasing $\mathrm{pH}$ using an automatic glass titration reactor operating at $50{ }^{\circ} \mathrm{C}$, under $\mathrm{N}_{2}$ flow. The chemicals were of analytical grade and used without any treatment (LiOH, Biotec (São Paulo, Brazil), 98\%; $\mathrm{NaOH}$, Reatec (São Paulo, Brazil), 99\%; KOH, Reatec, 98\%; $\mathrm{CuSO}_{4}$, Reatec, $99 \% ; \mathrm{Al}_{2}\left(\mathrm{SO}_{4}\right)_{3} .16 \mathrm{H}_{2} \mathrm{O}$, Reatec, 98-102\%; $\mathrm{Li}_{2} \mathrm{SO}_{4}$, Reatec, 99\%; $\mathrm{Na}_{2} \mathrm{SO}_{4}$, Neon (São Paulo, Brazil), 99.9\%; $\mathrm{K}_{2} \mathrm{SO}_{4}$, Reatec, $98.5 \%$; $\left(\mathrm{NH}_{4}\right)_{2} \mathrm{SO}_{4}$, Reatec, 99\%; $\mathrm{NaNO}_{3}$, F. Maia (Belo Horizonte, Brazil), $99 \% ; \mathrm{Na}_{2} \mathrm{CO}_{3}$, Biotec, 99\%). The amounts used in the synthesis of the samples are presented in Table 1.

Using the phase $\mathrm{Cu}_{2} \mathrm{Al}-\mathrm{SO}_{4} / \mathrm{Na}$ as an example, $\mathrm{CuSO}_{4} \cdot 5 \mathrm{H}_{2} \mathrm{O}, \mathrm{Al}_{2}\left(\mathrm{SO}_{4}\right)_{3}$ and $\mathrm{Na}_{2} \mathrm{SO}_{4}$ were dissolved in $100 \mathrm{~mL}$ of Milli-Q water (Millipore-simplicity UV, Bedford, USA). The solution was heated to $50{ }^{\circ} \mathrm{C}$ and very slowly titrated with a solution of $1 \mathrm{~mol} \mathrm{~L}^{-1} \mathrm{NaOH}$ in a glass titration reactor, using a peristaltic pump coupled to a pHmeter, having the $\mathrm{pH}$ monitored all the time during the titration. After observing that solid materials were obtained, the slurries were removed from the reactor at desired pHs and aged at $90{ }^{\circ} \mathrm{C}$ for $120 \mathrm{~h}$ in a capped Erlenmeyer flask. All the samples were separated by centrifugation at $4000 \mathrm{rpm}$ (centrifugal force of $2125 \mathrm{G}$ ) for $5 \mathrm{~min}$. To minimize the mechanically trapped soluble species, a new portion of around $50 \mathrm{~mL}$ of $\mathrm{N}_{2}$ decarbonated distilled water (by boiling and bubbling $\mathrm{N}_{2}$ gas) was added to the slurry and the tube submitted to one ultrasound bath for some seconds. The centrifugation was performed, and the process repeated at least five times and finally dried at room temperature. As per our experience in the lab, filtration is not a good procedure to remove all soluble species trapped between the particles in the cake.

After defining the optimal $\mathrm{pH}$ for synthesis of more crystalline materials (using the procedure of observing the sharp peaks and the higher number of the basal peaks in the XRD patterns), the samples were also synthesized with sulfate salts of lithium, potassium and ammonium and precipitated with $1 \mathrm{~mol} \mathrm{~L}^{-1}$ solutions of the respective hydroxides. Samples were also intercalated with nitrate and carbonate and precipitated with a $1 \mathrm{~mol} \mathrm{~L}^{-1} \mathrm{NaOH}$ solution. To observe the effect of the temperature in the sample crystallinity, the lithium sample was not hydrothermally treated at $90{ }^{\circ} \mathrm{C}$, only aged at room temperature for $120 \mathrm{~h}$.

Based on the sodium intercalated phase as an example of the exchange reactions, an aqueous dispersion of the solid was magnetically stirred slowly with excess $\mathrm{Li}_{2} \mathrm{SO}_{4}$, $\mathrm{K}_{2} \mathrm{SO}_{4}$ or $\left(\mathrm{NH}_{4}\right)_{2} \mathrm{SO}_{4}$ (three times the concentration of the intercalated cations) for $120 \mathrm{~h}$. The attempt to substitute nitrate and carbonate with sulfate occurred with an excess of $\mathrm{Na}_{2} \mathrm{SO}_{4}$ (five times the concentration of the intercalated cations) for $240 \mathrm{~h}$.

Table 1. Solution concentrations and $\mathrm{pH}$ changes during synthesis

\begin{tabular}{|c|c|c|c|c|c|}
\hline Compound & $\mathrm{CuSO}_{4} / \mathrm{mmol}$ & $\mathrm{Al}_{2}\left(\mathrm{SO}_{4}\right)_{3} / \mathrm{mmol}$ & $\mathrm{B}_{2} \mathrm{SO}_{4}{ }^{\mathrm{a}} / \mathrm{mmol}$ & Initial $\mathrm{pH}$ & Final $\mathrm{pH}$ \\
\hline $\mathrm{Cu}_{2} \mathrm{Al}-\mathrm{SO}_{4} / \mathrm{Li}$ & 25.354 & 6.339 & 2.113 & 3.06 & 8.01 \\
\hline $\mathrm{Cu}_{2} \mathrm{Al}-\mathrm{SO}_{4} / \mathrm{Na}$ & 25.015 & 6.254 & 2.085 & 3.05 & 8.02 \\
\hline $\mathrm{Cu}_{2} \mathrm{Al}-\mathrm{SO}_{4} / \mathrm{K}$ & 24.684 & 6.171 & 2.057 & 3.08 & 8.04 \\
\hline $\mathrm{Cu}_{2} \mathrm{Al}-\mathrm{SO}_{4} / \mathrm{NH}_{4}$ & 25.117 & 6.281 & 2.093 & 2.85 & 8.02 \\
\hline Compound & $\mathrm{Cu}\left(\mathrm{NO}_{3}\right)_{2} / \mathrm{mmol}$ & $\mathrm{Al}\left(\mathrm{NO}_{3}\right)_{3} / \mathrm{mmol}$ & $\mathrm{NaNO}_{3}$ or $\mathrm{Na}_{2} \mathrm{CO}_{3} / \mathrm{mmol}$ & Initial $\mathrm{pH}$ & Final $\mathrm{pH}$ \\
\hline $\mathrm{Cu}_{2} \mathrm{Al}-\mathrm{NO}_{3}$ & 28.243 & 14.121 & 4.709 & 3.25 & 8.17 \\
\hline $\mathrm{Cu}_{2} \mathrm{Al}-\mathrm{CO}_{3}$ & 28.404 & 14.200 & 2.365 & 4.02 & 8.07 \\
\hline
\end{tabular}

${ }^{\mathrm{a}} \mathrm{B}=\mathrm{Li}^{+}, \mathrm{Na}^{+}, \mathrm{K}^{+}, \mathrm{NH}_{4}^{+}$. 
The reactions were performed at room temperature under $\mathrm{N}_{2}$ flow to avoid contamination with carbonate. After the reactions, the materials were centrifuged at $4000 \mathrm{rpm}$, washed several times with decarbonated distilled water and dried at room temperature. For the exchange reactions in the other synthesized phases, combinations of different alkaline metal sulfates were used.

The compounds were characterized by X-ray diffraction (XRD) using a Shimadzu XRD-6000 diffractometer with $\mathrm{Cu} \mathrm{K} \alpha=1.5418 \AA$ $\mathrm{\text {radiation,tension }}$ of $40 \mathrm{kV}$, current of $30 \mathrm{~mA}$ and dwell time of $2^{\circ} \mathrm{min}^{-1}$ (the step was of $0.02^{\circ}$ in $2 \theta$ ). For the analysis, the samples were dispersed in water after the last washing and were deposited in the glass sample holders and allowed to dry at room temperature.

Fourier-transform infrared (FTIR) spectra were obtained in the transmission mode using a Bomen MB100 spectrophotometer using $\mathrm{KBr}$ pellets containing around $1 \%(\mathrm{~m} / \mathrm{m})$ of the sample. The spectra were collected from $400-4000 \mathrm{~cm}^{-1}$, with 32 scans, using resolution of $2 \mathrm{~cm}^{-1}$.

The morphology was investigated by scanning electron microscopy (SEM). The images were acquired with a Tescan Vega3LMU microscope with AZ Tech software. The samples were deposited on carbon tapes and sputtered with a thin gold layer.

The quantitative determinations of the metals and sulfur (relative to sulfate) were quantified with a Thermo Scientific inductively coupled plasma optical emission spectrometer (ICP OES, model iCAP 6500) with the Thermo Scientific iTeVa software, version 1.2.0.30. The samples were dissolved in a solution containing $1.0 \% \mathrm{v} / \mathrm{v}$ of $\mathrm{HNO}_{3}$ in Milli-Q water and the data were collected in duplicate. Average values were used to obtain the LDH formulas.

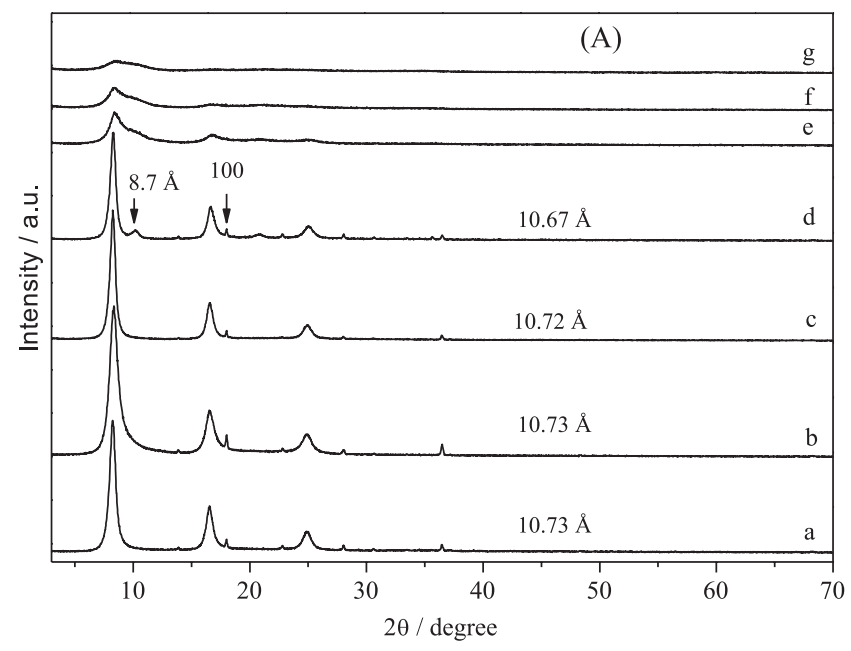

Thermogravimetric analyses (TGA) were performed with a PerkinElmer TGA 4000 equipment, under synthetic air atmosphere with a flow rate of $50 \mathrm{~mL} \mathrm{~min}^{-1}$ and heating rate of $10{ }^{\circ} \mathrm{C} \mathrm{min}^{-1}$.

\section{Results and Discussion}

In spite of the antecedents in the literature ${ }^{29,43}$ indicating the difficulty or impossibility to obtain crystalline $\mathrm{Cu}$ rich $\mathrm{Al}$ LDH phases, it was a surprise when the XRD patterns of most of samples (Figure 1A) presented the typical pattern of this class of compounds, with a series of strong basal diffraction peaks due to the natural orientation of the layered crystals in the sample holder plane. The basal distances of compounds, indicated in the figure, were determined by Bragg's law using the peak of highest order (around $25^{\circ}$ in $2 \theta$ ).

For all samples of $\mathrm{Cu}_{2} \mathrm{Al}-\mathrm{SO}_{4} / \mathrm{Na}$ obtained in the investigated $\mathrm{pH}$ range, the basal distance was close to $11 \AA$, with slight reduction when the $\mathrm{pH}$ of synthesis increased. In all cases, the basal distance was typical of systems containing sulfate and alkali metals, obtained by direct synthesis or exchange reactions. ${ }^{13,44} \mathrm{At} \mathrm{pH}=8.51$, contamination was found with basal spacing of $8.7 \AA$, which is consistent with the intercalation of dehydrated sulfate. ${ }^{1}$ After $\mathrm{pH}=8.51$, the samples lost crystallinity, tending to amorphous materials at $\mathrm{pH}$ higher than 10. In all samples, the (100) diffraction peaks were observed, indicating that the sample had a superstructure of the $a^{\prime}=a \sqrt{3} \times a \sqrt{3}$ type ( $\mathrm{a}^{\prime}=5.33 \AA$, $\mathrm{a}=3.08 \AA$, average distance between the metals in the brucite-like layers), as expected for LDHs with $2 \mathrm{M}^{2+}: \mathrm{M}^{3+}$, due to the metal cations' ordering in the twodimensional layers. ${ }^{16,44-46}$ The "a" parameter is very close to that of $\mathrm{Cu} / \mathrm{Al}-\mathrm{CO}_{3} \mathrm{LDH}^{47}(\mathrm{a}=3.08 \AA)$ and of the mineral

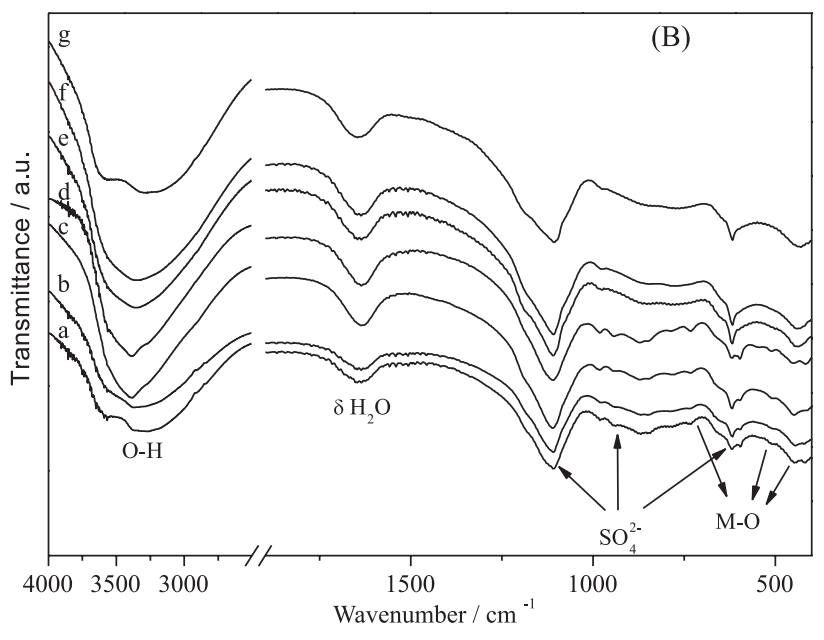

Figure 1. (A) XRD patterns and (B) FTIR spectra of the $\mathrm{Cu}_{2} \mathrm{Al}_{-}-\mathrm{SO}_{4} / \mathrm{Na}$ synthesized at different pH values: (a) 7.03; (b) 7.57; (c) 8.04; (d) 8.51; (e) 9.07 ; (f) 9.55 and (g) 10.03 . 
woodwardite $\left(\mathrm{Cu}_{4} \mathrm{Al}_{2}(\mathrm{OH})_{12}\left(\mathrm{SO}_{4}\right)\left(\mathrm{H}_{2} \mathrm{O}\right)_{2-4}\right)(\mathrm{a}=3.10 \AA)^{48}$ and hydrowoodwardite $\left(\mathrm{Cu}_{1-\mathrm{x}} \mathrm{Al}_{\mathrm{x}}(\mathrm{OH})_{2}\left(\mathrm{SO}_{4}\right)_{\mathrm{x} / 2} \cdot \mathrm{nH}_{2} \mathrm{O}\right)$ $(\mathrm{a}=3.07 \AA) .{ }^{49}$ For comparison purposes, the basal distances of hydrowoodwardite, shigaite, motukoreaite and natroglaucocerinite are of 10.93, 11.02, 11.17 and $11.18 \AA$, respectively. ${ }^{14-16,49}$ Woodwardite is the dehydrated analogous of hydrowoodwardite, consequently the basal distance is of $8.92 \AA . .^{48}$ This value is close to the impurity observed in the phase $\mathrm{Cu}_{2} \mathrm{Al}-\mathrm{SO}_{4} / \mathrm{Na}$ obtained at $\mathrm{pH}=8.51$ (Figure 1A, curve d) and also in the low crystalline phase $\mathrm{Cu}_{2} \mathrm{Al}-\mathrm{SO}_{4} / \mathrm{Li}$ (Figure 2A, curve a).

Very similar FTIR spectra were obtained for all the samples (Figure 1B), with the characteristic bands of the $\mathrm{O}-\mathrm{H}$ bond stretching $\left(3400 \mathrm{~cm}^{-1}\right.$ region), referring to the structure of hydroxyls and adsorbed water molecules, besides the band at $1640 \mathrm{~cm}^{-1}$, corresponding to water molecule bending. ${ }^{4,50-53}$ The band in the region of $1120 \mathrm{~cm}^{-1}$ was attributed to the $v_{3}$ asymmetrical bending, while the bands at 960 and $620 \mathrm{~cm}^{-1}$ were attributed to $v_{1}$ and $v_{4} \mathrm{~S}-\mathrm{O}$ vibrations. The broadening of the bands suggests that sulfate anions are in a highly distorted environment. All compounds also presented typical bands in the region of 425-450, 533 and $735 \mathrm{~cm}^{-1}$, which can be attributed to the $\mathrm{O}-\mathrm{M}-\mathrm{O}$ deformation mode and $\mathrm{M}-\mathrm{O}$ stretching vibrations. ${ }^{11,52-56}$ FTIR spectra are consistent with other copper-containing LDHs and minerals containing sulfate and alkali metals. ${ }^{34,35,37,57}$

In the $\mathrm{LDH}$ of $\mathrm{Al}$ with other metals like $\mathrm{Mn}^{2+}, \mathrm{Mg}^{2+}$ and $\mathrm{Zn}^{2+}$, the bands were sharper, indicating a defined sulfate environment, ${ }^{13}$ but were also broad in the LDHs of $\mathrm{Al}$ with $\mathrm{Ni}^{2+}$ and $\mathrm{Co}^{2+} .{ }^{17}$ As observed for XRD patterns, after $\mathrm{pH}$ 8.51, some FTIR bands became very weak and even disappeared in the range below $1000 \mathrm{~cm}^{-1}$, but sulfate was still detected in all of them.

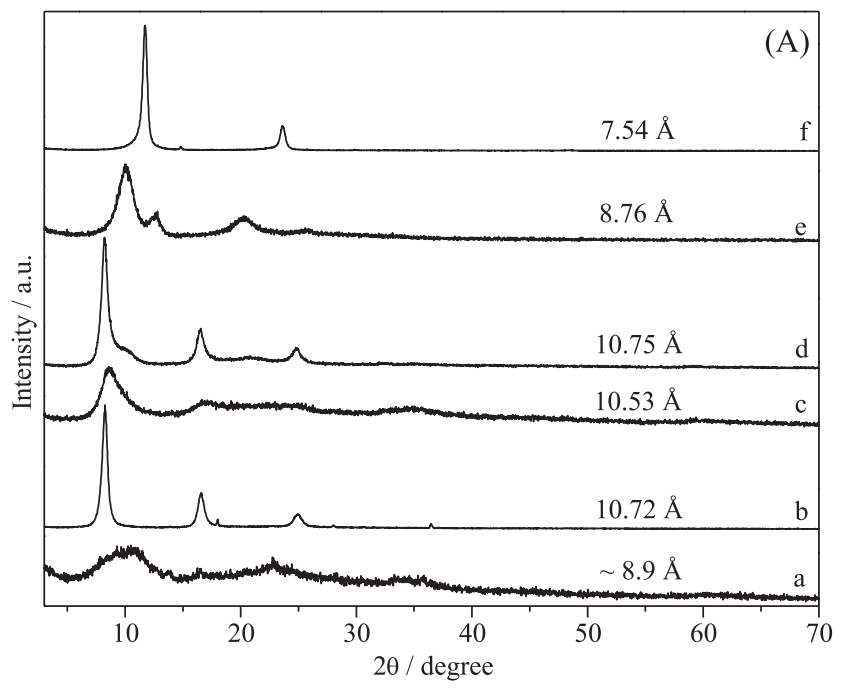

Several attempts were made to synthesize the phase of $\mathrm{Cu}_{2} \mathrm{Al}-\mathrm{SO}_{4} / \mathrm{NH}_{4}$, but after changing the $\mathrm{pH}$ and temperature of synthesis, the reproducibility was very difficult. Phases with basal distances of 8.20-8.5 and $10.7 \AA$ were obtained even under the same synthesis conditions. These phases were consistent with the structure of woodwardite $\left(\mathrm{Cu}_{4} \mathrm{Al}_{2}(\mathrm{OH})_{12}\left(\mathrm{SO}_{4}\right)\left(\mathrm{H}_{2} \mathrm{O}\right)_{2-4}\right)^{49}$ and a synthetic analog with the composition $\mathrm{Cu}_{0.67} \mathrm{Al}_{0.33}(\mathrm{OH})_{2}\left(\mathrm{SO}_{4}\right)_{0.15}\left(\mathrm{CO}_{3}\right)_{0.015} \cdot 0.5 \mathrm{H}_{2} \mathrm{O},{ }^{58,59}$ respectively with basal distances of 8.92 and $8.58 \AA$, close to the reported values ${ }^{60}$ for $\mathrm{LDH}$ without copper, which are highly dependent on the degree of hydration.

The phase of $10.7 \AA$ can be related to the presence of ammonium and excess sulfate as in shigaite-like structures, ${ }^{14-16}$ or materials containing sulfate with high degree of hydration, as observed in hydrowoodwardite or synthetic hydrated $\mathrm{Cu}_{0.667} \mathrm{Al}_{0.333}(\mathrm{OH})_{2}\left(\mathrm{SO}_{4}\right)_{0.1665} \cdot \mathrm{nH}_{2} \mathrm{O} .{ }^{46}$ Due to this difficulty, the phases with the composition $\mathrm{Cu}_{2} \mathrm{Al}$ $\mathrm{SO}_{4} / \mathrm{NH}_{4}$ and basal distance of $10.75 \AA$, more frequently observed in the synthesis, will be described.

In the XRD patterns, the phases synthesized with sodium $(c=10.72 \AA)$ and ammonium $(c=10.75 \AA)$ showed intense and defined peaks (Figure 2A, curves $\mathrm{b}$ and $\mathrm{d}$ ), indicating greater crystallinity than the other sulfate phases. $\mathrm{Cu}_{2} \mathrm{Al}_{-} \mathrm{SO}_{4} / \mathrm{K}$ (Figure $2 \mathrm{~A}$, curve c) $(\mathrm{c}=10.53 \AA$ ) presented intermediary crystallinity while $\mathrm{Cu}_{2} \mathrm{Al}-\mathrm{SO}_{4} / \mathrm{Li}$ (Figure $2 \mathrm{~A}$, curve a) (c ca. $8.9 \AA$ ) presented the lowest crystallinity due to the absence of the ripening process. Other LDHs intercalated with sulfate or sulfate/alkali metals have been reported ${ }^{13,15,17,61-64}$ with similar basal spacing, but the sulfate quickly dehydrated after exposure to dry air, which did not happen to our samples.

This indicates that our samples did not contain only sulfate, since samples containing sulfate/alkali metals are

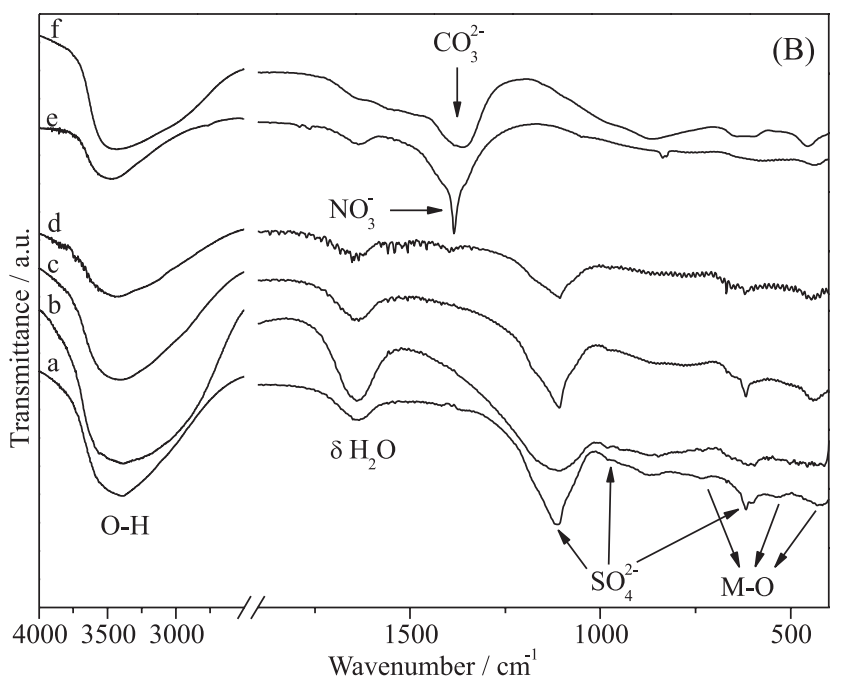

Figure 2. (A) XRD patterns and (B) FTIR spectra of (a) $\mathrm{Cu}_{2} \mathrm{Al}-\mathrm{SO}_{4} / \mathrm{Li}$; (b) $\mathrm{Cu}_{2} \mathrm{Al}-\mathrm{SO}_{4} / \mathrm{Na}$; (c) $\mathrm{Cu}_{2} \mathrm{Al}-\mathrm{SO}_{4} / \mathrm{K}$; (d) $\mathrm{Cu}_{2} \mathrm{Al}_{-}-\mathrm{SO}_{4} / \mathrm{NH}_{4}$; (e) $\mathrm{Cu}_{2} \mathrm{Al}-\mathrm{NO}_{3}$ and (f) $\mathrm{Cu}_{2} \mathrm{Al}-\mathrm{CO}_{3}$. The pHs of the syntheses are described in Table 1 . 
stable in air, preserving basal distances close to $11 \AA$ A. For the $\mathrm{Cu}_{2} \mathrm{Al}-\mathrm{NO}_{3}$ and $\mathrm{Cu}_{2} \mathrm{Al}-\mathrm{CO}_{3}$ (Figure 2A, curves e and f), the basal distances of 8.76 and $7.54 \AA$, respectively, are characteristic of nitrate and carbonate intercalation. ${ }^{8,47,65,66}$ The $\mathrm{Cu}_{2} \mathrm{Al}-\mathrm{NO}_{3}$ compound showed a diffraction peak with basal distance close to $7.3 \AA$, which can be attributed to carbonate contamination, although the reactions were performed under $\mathrm{N}_{2}$ flow.

In compounds synthesized with sulfate (Figure 2B, curves $\mathrm{a}-\mathrm{d}$ ), the bands were very similar to those observed in Figure 1B. $\mathrm{Cu}_{2} \mathrm{Al}-\mathrm{NO}_{3}$ and $\mathrm{Cu}_{2} \mathrm{Al}-\mathrm{CO}_{3}$ (Figure 2B, curves e and $\mathrm{f}$ ) showed the characteristic bands of the respective anions intercalated with the stretching vibration of the $\mathrm{C}-\mathrm{O}$ and $\mathrm{N}-\mathrm{O}$ bonds, located at 1360 and $1380 \mathrm{~cm}^{-1}$, respectively. ${ }^{3,27,67-69}$ The $\mathrm{Cu} / \mathrm{Al}-\mathrm{NO}_{3}$ sample showed broadening of the $\mathrm{N}-\mathrm{O}$ band $\left(1380 \mathrm{~cm}^{-1}\right)$ towards the $1360 \mathrm{~cm}^{-1}$ region, attributed to carbonate contamination, as shown in the XRD pattern. Table 2 reports the chemical composition of the synthesized samples obtained in the ICP OES analysis. For the samples containing lithium and sodium, the results were close to the values used in the synthesis and the chemical composition was consistent with the ideal anhydrous formula $\left[\mathrm{Cu}_{0.667} \mathrm{Al}_{0.333}(\mathrm{OH})_{2}\right]\left[\mathrm{B}_{0.111}\left(\mathrm{SO}_{4}\right)_{0.222}\right]$ $\left(\mathrm{B}=\mathrm{Li}^{+}, \mathrm{Na}^{+}\right)$.
Table 2. Compositions of the synthesized phases obtained by ICP OES analysis

\begin{tabular}{lccccc}
\hline Compound & $\mathrm{Cu}^{2+}$ & $\mathrm{Al}^{3+}$ & $\mathrm{SO}_{4}{ }^{2-}$ & $\mathrm{CO}_{3}{ }^{2-} / \mathrm{NO}_{3}{ }^{-}$ & $\mathrm{B}^{+\mathrm{a}}$ \\
\hline $\mathrm{Cu}_{2} \mathrm{Al}-\mathrm{SO}_{4} / \mathrm{Li}$ & 0.648 & 0.352 & 0.210 & & 0.115 \\
$\mathrm{Cu}_{2} \mathrm{Al}-\mathrm{SO}_{4} / \mathrm{Na}$ & 0.663 & 0.337 & 0.217 & & 0.108 \\
$\mathrm{Cu}_{2} \mathrm{Al}-\mathrm{SO}_{4} / \mathrm{K}$ & 0.643 & 0.357 & $0.151^{\mathrm{b}}$ & & 0.017 \\
$\mathrm{Cu}_{2} \mathrm{Al}-\mathrm{SO}_{4} / \mathrm{NH}_{4}$ & 0.662 & 0.338 & $0.179^{\mathrm{b}}$ & & n.e. \\
$\mathrm{Cu}_{2} \mathrm{Al}-\mathrm{CO}_{3}$ & 0.670 & 0.330 & & n.e. & n.d. \\
$\mathrm{Cu}_{2} \mathrm{Al}_{-}-\mathrm{NO}_{3}$ & 0.659 & 0.341 & & n.e. & n.d. \\
\hline
\end{tabular}

Ideal composition of anhydrous sample $\left[\mathrm{Cu}_{0.667} \mathrm{Al}_{0.333}(\mathrm{OH})_{2}\right]\left[\mathrm{B}_{0.111}\left(\mathrm{SO}_{4}\right)_{0.222}\right]$. ${ }^{\mathrm{a}} \mathrm{B}^{+}=(\mathrm{Li}, \mathrm{Na}, \mathrm{K})$; ${ }^{\text {bclose }}$ to the formula $\mathrm{Cu}_{0.667} \mathrm{Al}_{0.333}(\mathrm{OH})_{2}\left(\mathrm{SO}_{4}\right)_{0.1665}$. n.e.: not evaluated; n.d.: not detected.

Since XRD patterns indicated basal spacing typical of a compound with $\mathrm{SO}_{4}{ }^{2-} / \mathrm{NH}_{4}{ }^{+}$and the FTIR spectra indicated absence of $\mathrm{N}-\mathrm{H}$ bonds, the formula is close to $\mathrm{Cu}_{0.662} \mathrm{Al}_{0.338}(\mathrm{OH})_{2}\left(\mathrm{SO}_{4}\right)_{0.169}$ but the content of sulfate is slightly higher than predicted. In the case of $\mathrm{Cu}_{2} \mathrm{Al}-\mathrm{SO}_{4} / \mathrm{K}$, the contents of sulfate and potassium are reduced, indicating the possible composition $\mathrm{Cu}_{0.667} \mathrm{Al}_{0.333}(\mathrm{OH})_{2}\left(\mathrm{SO}_{4}\right)_{0.1665}$, although the basal distance also suggests the presence of $\mathrm{SO}_{4}^{2-}$ /alkali metal $(10.53 \AA)$ and ICP OES indicates the presence of some amount of potassium, but much lower
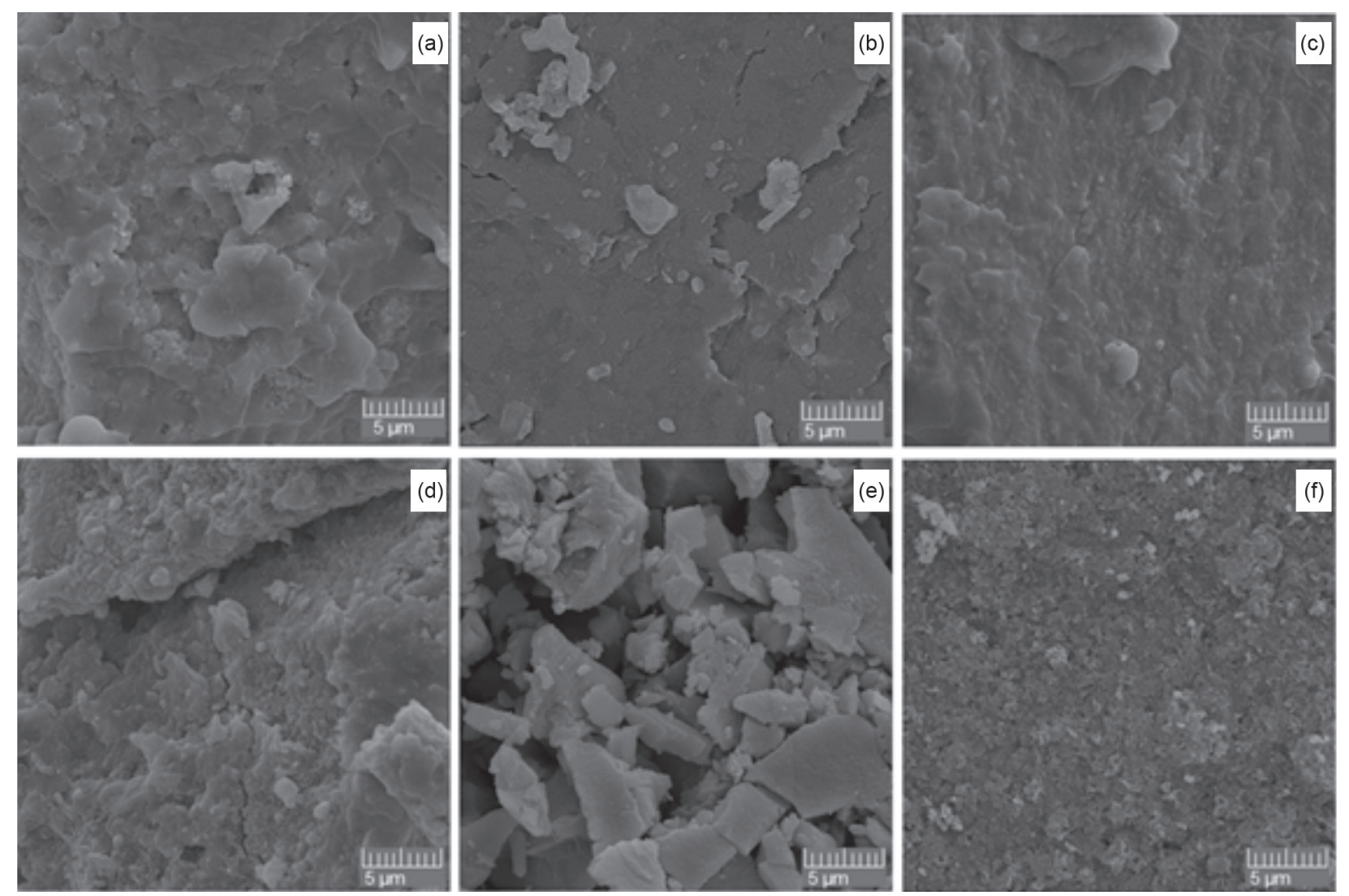

Figure 3. $\mathrm{SEM}$ images of (a) $\mathrm{Cu}_{2} \mathrm{Al}-\mathrm{SO}_{4} / \mathrm{Li}$; (b) $\mathrm{Cu} \mathrm{Al}_{2} \mathrm{Al}-\mathrm{SO}_{4} / \mathrm{Na}$; (c) $\mathrm{Cu}_{2} \mathrm{Al}-\mathrm{SO}_{4} / \mathrm{K}$; (d) $\mathrm{Cu}_{2} \mathrm{Al}_{-}-\mathrm{SO}_{4} / \mathrm{NH}_{4}$; (e) $\mathrm{Cu}_{2} \mathrm{Al}-\mathrm{NO}_{3}$ and (f) $\mathrm{Cu}_{2} \mathrm{Al}-\mathrm{CO}_{3}$. 
than expected (Table 2). The SEM images of all the samples (Figure 3) indicated a compact agglomeration and crystals with submicrometric size and platelet-like morphology, typical of LDHs. The orientation of the layered crystals in the sample holder explains the exposure of the basal planes to diffraction, as observed in the XRD patterns of all samples (Figures 1A and 2A).

The TGA and corresponding derivative thermogravimetry (DTG) curves (Figure 4) showed the same profile. In general, the release of intercalated and sorbed water occurs up to $220^{\circ} \mathrm{C} .{ }^{70}$ The second event up to $450{ }^{\circ} \mathrm{C}$ is attributed
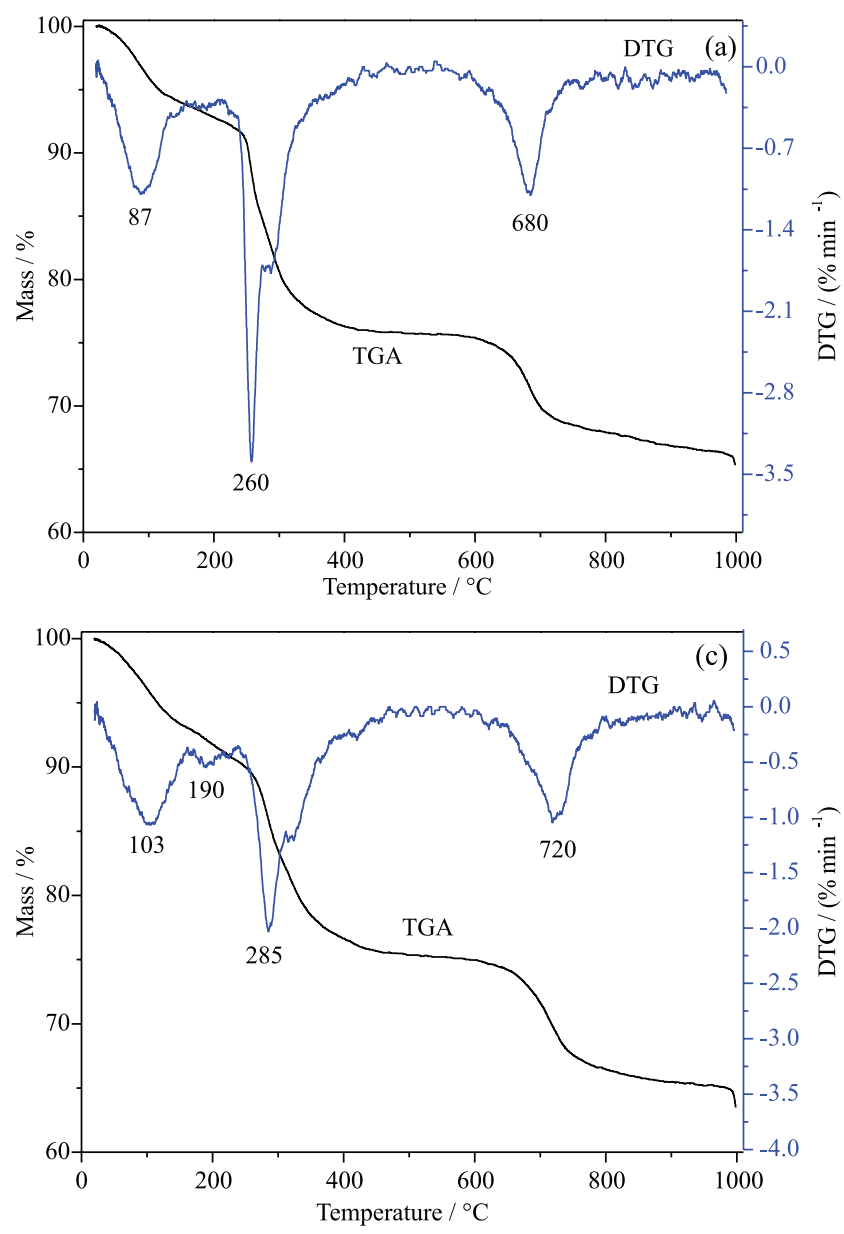

to the LDH dehydroxylation process, indicated by the DTG peak, which varied according to the intercalated alkali metal, as expected due to the different hydration energy of the intercalated cations. The third event indicated by the DTG peak in the region of $680-720^{\circ} \mathrm{C}$ is attributed to the partial decomposition of sulfates. ${ }^{71}$ In spite of the deviation between the expected and experimental values of up to $4 \%$ due to the partial decomposition of sulfates at $1000^{\circ} \mathrm{C}$ (see mass loss under way close to $1000^{\circ} \mathrm{C}$ ), there were relative good agreements between the experimental residual mass from the theoretical one (Table 3).
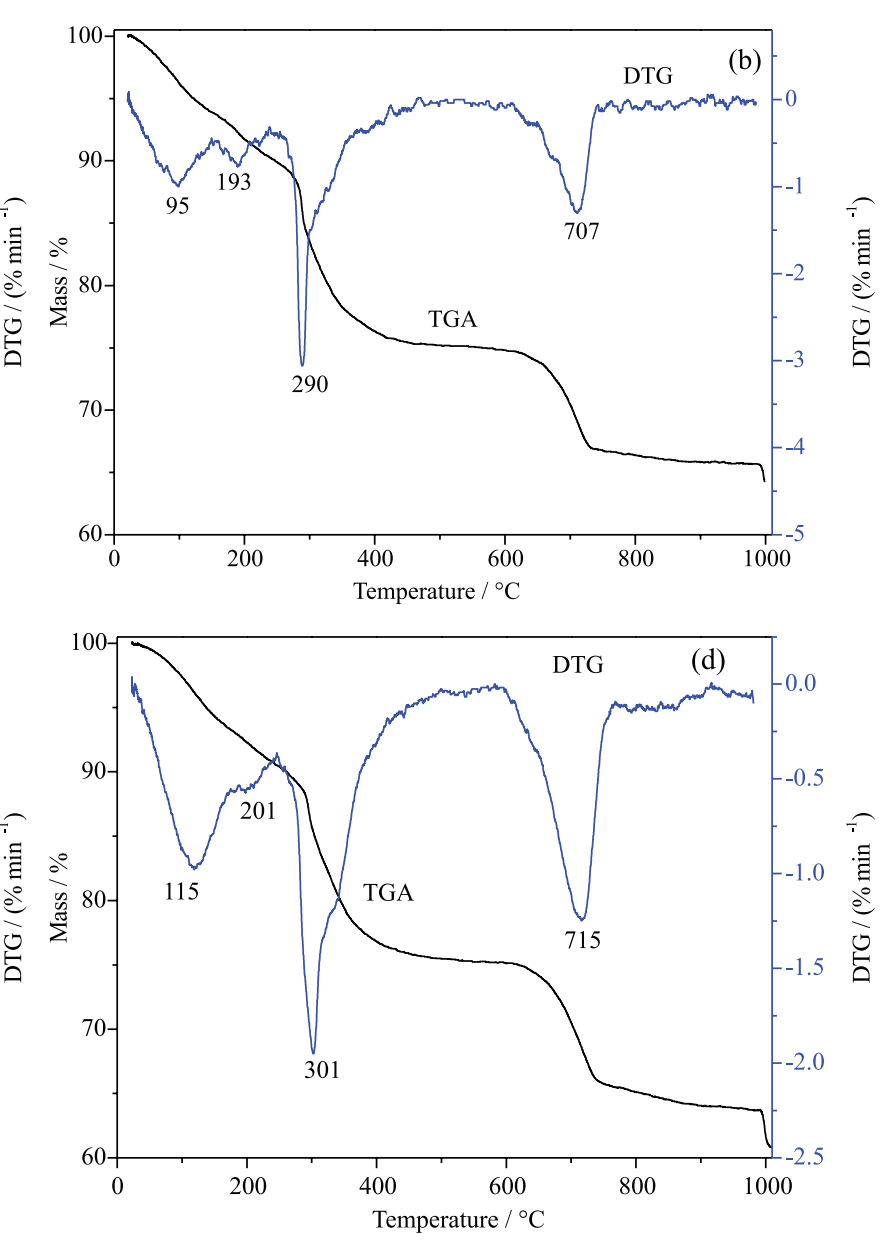

Figure 4. TGA/DTG curves of (a) $\mathrm{Cu}_{2} \mathrm{Al}-\mathrm{SO}_{4} / \mathrm{Li}$; (b) $\mathrm{Cu}_{2} \mathrm{Al}-\mathrm{SO}_{4} / \mathrm{Na}$; (c) $\mathrm{Cu}_{2} \mathrm{Al}-\mathrm{SO}_{4} / \mathrm{K}$ and (d) $\mathrm{Cu}_{2} \mathrm{Al}-\mathrm{SO}_{4} / \mathrm{NH}_{4}$.

Table 3. Proposed chemical formulas of the evaluated compounds

\begin{tabular}{lcccc}
\hline Compound & Mass $/ \%$ & Mass $^{\mathrm{b}} / \%$ & $\Delta / \%$ & $\begin{array}{c}\mathrm{H}_{2} \mathrm{O} \text { content }(\mathrm{y}) \\
\left(\text { temperature } /{ }^{\circ} \mathrm{C}\right)\end{array}$ \\
\hline $\mathrm{Cu}_{0.648} \mathrm{Al}_{0.352}(\mathrm{OH})_{2}\left(\mathrm{SO}_{4}\right)_{0.210}\left(\mathrm{CO}_{3}\right)_{0.024} \mathrm{Li}_{0.115} \cdot \mathrm{yH}_{2} \mathrm{O}$ & 66.488 & 69.009 & 3.79 & $0.30(130)$ \\
$\mathrm{Cu}_{0.663} \mathrm{Al}_{0.337}(\mathrm{OH})_{2}\left(\mathrm{SO}_{4}\right)_{0.217}\left(\mathrm{CO}_{3}\right)_{0.007} \mathrm{Na}_{0.108} \cdot \mathrm{yH}_{2} \mathrm{O}$ & 67.225 & 69.927 & 4.02 & $0.46(205)$ \\
$\mathrm{Cu}_{0.643} \mathrm{Al}_{0.357}(\mathrm{OH})_{2}\left(\mathrm{SO}_{4}\right)_{0.151}\left(\mathrm{CO}_{3}\right)_{0.036} \mathrm{~K}_{0.017} \cdot \mathrm{yH}_{2} \mathrm{O}$ & 68.883 & 70.010 & 1.64 & $0.51(238)$ \\
$\mathrm{Cu}_{0.662} \mathrm{Al}_{0.338}(\mathrm{OH})_{2}\left(\mathrm{SO}_{4}\right)_{0.179}\left(\mathrm{NH}_{4}\right)_{0.02} \cdot \mathrm{yH}_{2} \mathrm{O}$ & 68.016 & 66.500 & 2.23 & $0.55(250)$ \\
\hline
\end{tabular}

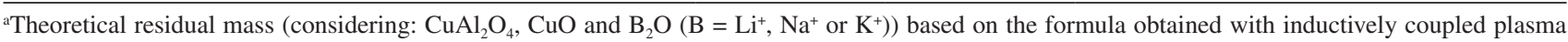
optical emission spectrometry (ICP OES), with inclusion of carbonate to balance the charges, and are in anhydrous form; bexperimental residual mass. $\Delta$ : deviation between the expected and experimental values. 
Although the literature ${ }^{44}$ describes the transformation of chloride and nitrate intercalated $\mathrm{LDH}$ into $\mathrm{SO}_{4}{ }^{2-} / \mathrm{B}^{+}$ $\left(\mathrm{B}^{+}=\right.$alkali metal $)$, our attempts to substitute interlayer nitrate and carbonate with sulfate produced materials with very low crystallinity indicating the unsuccessful reaction (data not shown).

The XRD patterns (Figure 5A) and FTIR spectra (Figure 5B) after the alkali metal cation exchange reactions showed basal distances close to $10 \AA$, typical of the presence of $\mathrm{SO}_{4}{ }^{2-} /$ alkali metal or hydrated sulfate.

The XRD patterns of compound $\mathrm{Cu}_{2} \mathrm{Al}-\mathrm{SO}_{4} / \mathrm{Li}(8.87 \AA)$ (Figure 5A, curve a) showed displacement to higher basal distance after the exchange reactions Li-Na (10.27 ̊) and Li-K (10.35 ̊) (Figure 5A, curves b and c). The basal distances of the samples $\mathrm{Cu}_{2} \mathrm{Al}-\mathrm{SO}_{4} / \mathrm{Na}$ after exchange

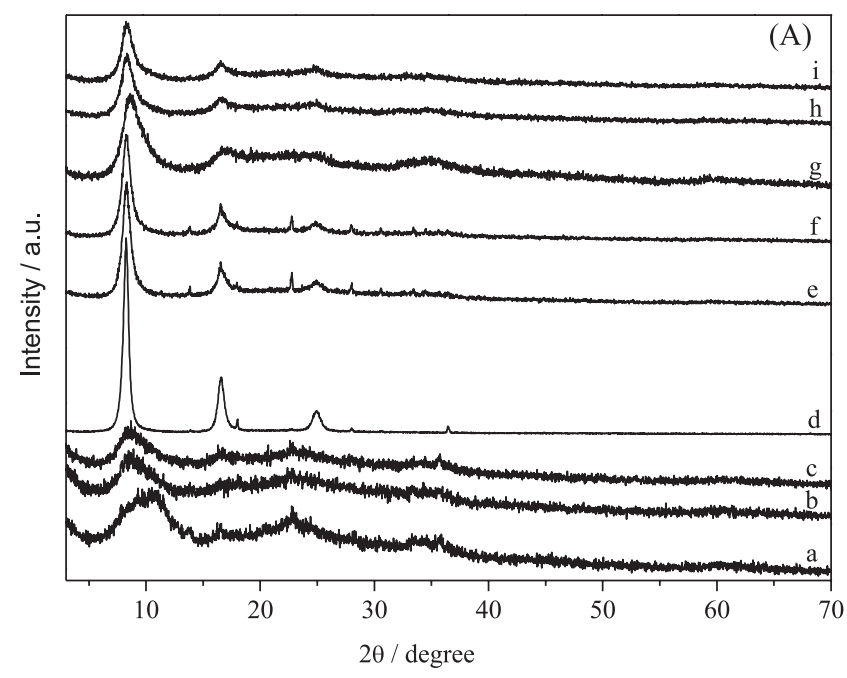

with $\mathrm{Li}^{+}$and $\mathrm{K}^{+}$changed from 10.72 to $10.70 \AA$ (Na-Li) and $10.75 \AA(\mathrm{Na}-\mathrm{K})$. In the case of $\mathrm{Cu}_{2} \mathrm{Al}-\mathrm{SO}_{4} / \mathrm{K}$, the basal distances changed from 10.53 to $10.50 \AA$ (K-Li) and $10.61 \AA$ (K-Na). This behavior has been observed previously ${ }^{13,17}$ in similar compounds synthesized with different $\mathrm{M}^{2+}$ and intercalated with sulfate and alkali metals.

The FTIR spectrum of the samples after exchanges (Figure 5B) shows the same bands as the precursors, indicating the maintenance of the basic LDH structure and functional groups. Traces of carbonate were observed in some samples (band at $1380 \mathrm{~cm}^{-1}$ ), but the concentration was very low. Table 4 presents the ICP OES data of the samples before and after the exchange reactions.

It can be seen that the samples $\mathrm{Cu}_{2} \mathrm{Al}-\mathrm{SO}_{4} / \mathrm{Li}$, $\mathrm{Cu}_{2} \mathrm{Al}-\mathrm{SO}_{4} / \mathrm{Na}$ and $\mathrm{Cu}_{2} \mathrm{Al}-\mathrm{SO}_{4} / \mathrm{NH}_{4}$, before the exchange

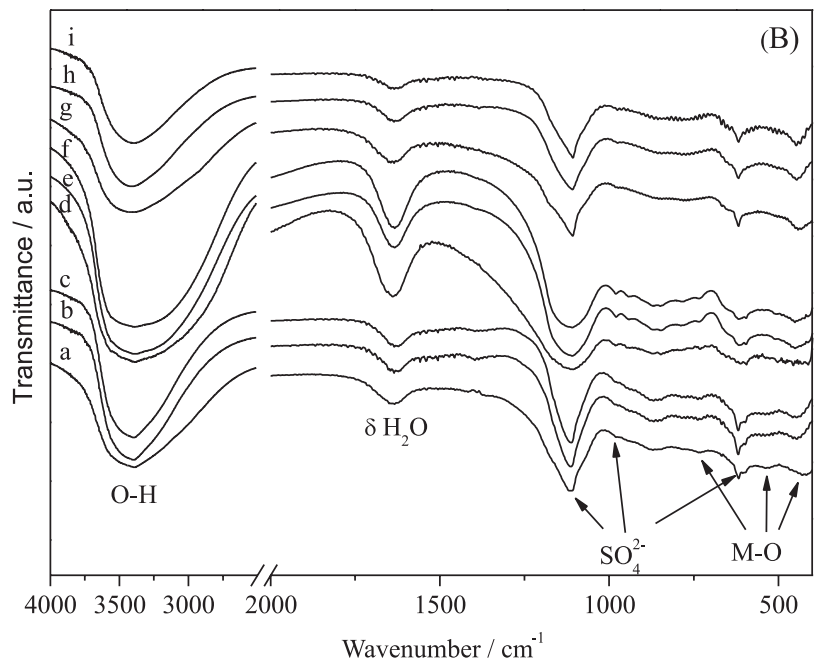

Figure 5. (A) XRD patterns and (B) FTIR spectra of (a) $\mathrm{Cu}_{2} \mathrm{Al}-\mathrm{SO}_{4} / \mathrm{Li}$ and after exchange with (b) $\mathrm{Na}$ and (c) $\mathrm{K}$; of (d) $\mathrm{Cu}_{2} \mathrm{Al}-\mathrm{SO}_{4} / \mathrm{Na}$ and after exchange with (e) $\mathrm{Li}$ and (f) $\mathrm{K}$; and of (g) $\mathrm{Cu}_{2} \mathrm{Al}-\mathrm{SO}_{4} / \mathrm{K}$ and after exchange with (h) $\mathrm{Li}$ and (i) $\mathrm{Na}$.

Table 4. Compositions of the samples obtained by ICP OES analysis

\begin{tabular}{|c|c|c|c|c|c|}
\hline Compound & $\mathrm{Cu}^{2+}$ & $\mathrm{Al}^{3+}$ & $\mathrm{SO}_{4}{ }^{2-}$ & Cation (B) & Ex. $^{\mathrm{a}} / \%$ \\
\hline $\mathrm{Cu}_{2} \mathrm{Al}-\mathrm{SO}_{4} / \mathrm{Li}$ & 0.648 & 0.352 & 0.210 & $\mathrm{Li}=0.115$ & - \\
\hline $\mathrm{Cu}_{2} \mathrm{Al}-\mathrm{SO}_{4} / \mathrm{Li}-\mathrm{Na}$ & 0.644 & 0.356 & $0.146^{\mathrm{b}}$ & $\mathrm{Li}=0.032 ; \mathrm{Na}=0.050 ; \mathrm{Li}+\mathrm{Na}=0.082$ & 60.98 \\
\hline $\mathrm{Cu}_{2} \mathrm{Al}-\mathrm{SO}_{4} / \mathrm{Li}-\mathrm{K}$ & 0.631 & 0.369 & $0.158^{\mathrm{b}}$ & $\mathrm{Li}=0.038 ; \mathrm{K}=0.011 ; \mathrm{Li}+\mathrm{K}=0.049$ & 22.45 \\
\hline $\mathrm{Cu}_{2} \mathrm{Al}-\mathrm{SO}_{4} / \mathrm{Na}$ & 0.663 & 0.337 & 0.217 & $\mathrm{Na}=0.108$ & - \\
\hline $\mathrm{Cu}_{2} \mathrm{Al}-\mathrm{SO}_{4} / \mathrm{Na}-\mathrm{Li}$ & 0.667 & 0.333 & 0.213 & $\mathrm{Na}=0.015 ; \mathrm{Li}=0.086 ; \mathrm{Na}+\mathrm{Li}=0.101$ & 85.15 \\
\hline $\mathrm{Cu}_{2} \mathrm{Al}-\mathrm{SO}_{4} / \mathrm{Na}-\mathrm{K}$ & 0.663 & 0.337 & 0.214 & $\mathrm{Na}=0.013 ; \mathrm{K}=0.088 ; \mathrm{Na}+\mathrm{K}=0.101$ & 87.13 \\
\hline $\mathrm{Cu}_{2} \mathrm{Al}-\mathrm{SO}_{4} / \mathrm{Na}-\mathrm{NH}_{4}$ & 0.661 & 0.339 & 0.208 & $\mathrm{Na}=0.066 ; \mathrm{NH}_{4}=$ n.e. & - \\
\hline $\mathrm{Cu}_{2} \mathrm{Al}-\mathrm{SO}_{4} / \mathrm{K}$ & 0.643 & 0.357 & $0.151^{\mathrm{b}}$ & $\mathrm{K}=0.017$ & - \\
\hline $\mathrm{Cu}_{2} \mathrm{Al}-\mathrm{SO}_{4} / \mathrm{K}-\mathrm{Li}$ & 0.646 & 0.354 & $0.139^{\mathrm{b}}$ & $\mathrm{K}=0.001 ; \mathrm{Li}=0.008 ; \mathrm{K}+\mathrm{Li}=0.009$ & 88.89 \\
\hline $\mathrm{Cu}_{2} \mathrm{Al}-\mathrm{SO}_{4} / \mathrm{K}-\mathrm{Na}$ & 0.648 & 0.352 & $0.136^{\mathrm{b}}$ & $\mathrm{K}=0.004 ; \mathrm{Na}=0.051 ; \mathrm{K}+\mathrm{Na}=0.055$ & 92.73 \\
\hline $\mathrm{Cu}_{2} \mathrm{Al}-\mathrm{SO}_{4} / \mathrm{NH}_{4}$ & 0.662 & 0.338 & $0.179^{\mathrm{b}}$ & - & - \\
\hline $\mathrm{Cu}_{2} \mathrm{Al}-\mathrm{SO}_{4} / \mathrm{NH}_{4}-\mathrm{Na}$ & 0.660 & 0.344 & $0.172^{\mathrm{b}}$ & $\mathrm{Na}=0.058 ; \mathrm{NH}_{4}=$ n.e. & - \\
\hline
\end{tabular}

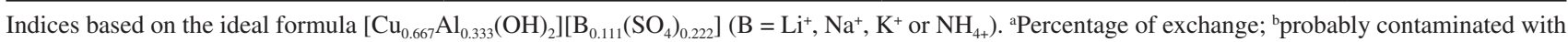
carbonate or the formula is close to $\left[\mathrm{Cu}_{0.667} \mathrm{Al}_{0.333}(\mathrm{OH})_{2}\right]\left(\mathrm{SO}_{4}\right)_{0.1665}$. n.e.: not evaluated. 
reactions present the chemical composition close to the expected ideal formula equivalent to the shigaitelike minerals $\left(\left[\mathrm{Cu}_{0.667} \mathrm{Al}_{0.333}(\mathrm{OH})_{2}\right]\left[\mathrm{B}_{0.111}\left(\mathrm{SO}_{4}\right)_{0.222}\right] ; \mathrm{B}=\right.$ $\left.\mathrm{Li}^{+}, \mathrm{NH}_{4}{ }^{+}\right),{ }^{14-17}$ while the sample $\mathrm{Cu}_{2} \mathrm{Al}-\mathrm{SO}_{4} / \mathrm{K}$ had a composition equivalent to the mineral hydrowoodwardite or synthetic analogous $\left(\mathrm{Cu}_{0.667} \mathrm{Al}_{0.333}(\mathrm{OH})_{2}\left(\mathrm{SO}_{4}\right)_{0.1665}\right)$.

After the exchange reactions of $\mathrm{Cu}_{2} \mathrm{Al}-\mathrm{SO}_{4} / \mathrm{Li}$, the content of sulfate and alkali metal was reduced, and the samples tended to be transformed into hydrowoodwardite. The $\mathrm{Cu}_{2} \mathrm{Al}-\mathrm{SO}_{4} / \mathrm{Na}$ sample was the only one that preserved the structure of shigaite-like minerals, with the presence of alkali metal and sulfate. $\mathrm{Cu}_{2} \mathrm{Al}-\mathrm{SO}_{4} / \mathrm{K}$ after the exchange reactions, although with a small concentration of alkali metal cations, especially after the exchange of $\mathrm{K}^{+}$with $\mathrm{Na}^{+}$, suggests the preservation of the hydrowoodwardite structure. The same was also observed for the sample $\mathrm{Cu}_{2} \mathrm{Al}-\mathrm{SO}_{4} / \mathrm{NH}_{4}$, after the exchange reactions.

Figure 6A shows the XRD patterns of the sodium and ammonium samples after the exchange reactions.

The compounds $\mathrm{Cu}_{2} \mathrm{Al}-\mathrm{SO}_{4} / \mathrm{Na}$ and $\mathrm{Cu}_{2} \mathrm{Al}-\mathrm{SO}_{4} / \mathrm{NH}_{4}$ showed basal distances of 10.72 and $10.75 \AA$, respectively. After the exchange reactions, $\mathrm{Cu}_{2} \mathrm{Al}-\mathrm{SO}_{4} / \mathrm{Na}-\mathrm{NH}_{4}$ had basal distance of $10.94 \AA$, while $\mathrm{Cu}_{2} \mathrm{Al}-\mathrm{SO}_{4} / \mathrm{NH}_{4}-\mathrm{Na}$ had basal distance of $10.73 \AA$. By XRD analysis, it was not possible to tell whether the cation exchange occurred, nor was this possible from the FTIR spectra (Figure 6B), which showed only broadening of some bands due to disturbance of the sulfate $/ \mathrm{Na}^{+}$or $\mathrm{NH}_{4}{ }^{+}$environment. The samples with the composition $\left[\mathrm{Cu}_{0.667} \mathrm{Al}_{0.333}(\mathrm{OH})_{2}\right]$ $\left[\mathrm{B}_{0.111}\left(\mathrm{SO}_{4}\right)_{0.222}\right]\left(\mathrm{B}=\mathrm{Li}^{+}, \mathrm{Na}^{+}, \mathrm{K}^{+}\right.$and $\left.\mathrm{NH}_{4}^{+}\right)$and $\mathrm{Cu}_{0.667} \mathrm{Al}_{0.333}(\mathrm{OH})_{2}\left(\mathrm{SO}_{4}\right)_{0.1665}$ have very similar basal distances and only precise chemical analyses would give the information about the real compositions of the evaluated materials.

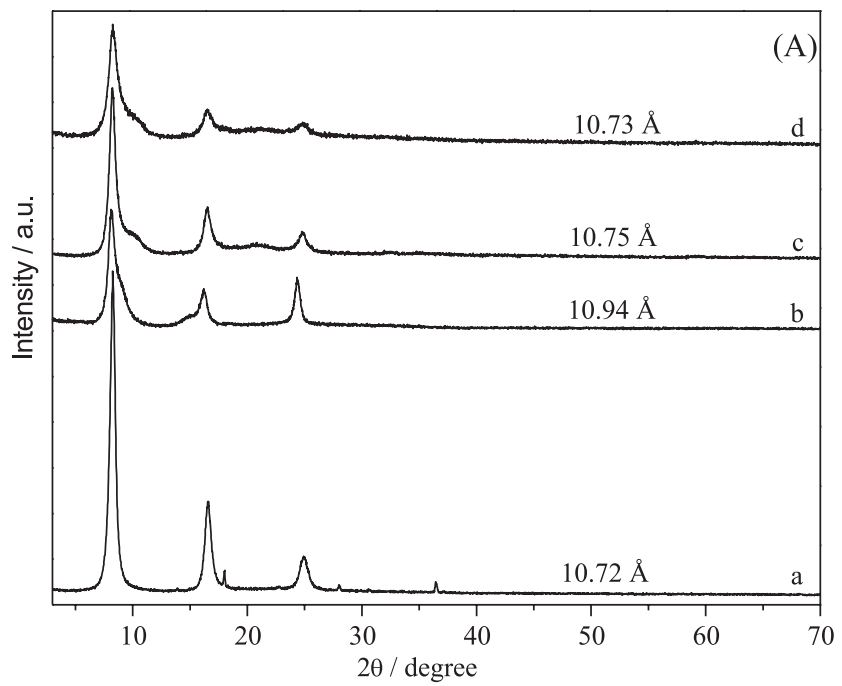

The SEM images (Figure 7) of all the $\mathrm{Cu} / \mathrm{Al}$ like phases after the exchange reactions showed agglomerated particles, but less compacted than in the precursors, possibly due to the magnetic stirring during the reactions.

The ideal compositions of the synthesized LDHs can be described by equations 1 to 14 (to avoid the indication of soluble product, at the right of the arrows only the solids were included).

\section{Synthesis}

Precipitation of $\mathrm{Cu}$ and $\mathrm{Al}$ sulfates in the presence of sodium and lithium sulfates $\left(\mathrm{B}=\mathrm{Li}^{+}\right.$or $\left.\mathrm{Na}^{+}\right)$:

$$
\begin{aligned}
& 0.667 \mathrm{CuSO}_{4}+0.1665 \mathrm{Al}_{2}\left(\mathrm{SO}_{4}\right)_{3}+\mathrm{B}_{2} \mathrm{SO}_{4}+\mathrm{BOH} \rightarrow \\
& \mathrm{Cu}_{0.667} \mathrm{Al}_{0.333}(\mathrm{OH})_{2}\left(\mathrm{SO}_{4}\right)_{0.211} \mathrm{~B}_{0.111}
\end{aligned}
$$

Precipitation of $\mathrm{Cu}$ and $\mathrm{Al}$ sulfates in the presence of potassium and ammonium sulfates $\left(\mathrm{B}=\mathrm{K}^{+}\right.$or $\left.\mathrm{NH}_{4}^{+}\right)$:

$0.667 \mathrm{CuSO}_{4}+0.1665 \mathrm{Al}_{2}\left(\mathrm{SO}_{4}\right)_{3}+\mathrm{B}_{2} \mathrm{SO}_{4}+\mathrm{BOH} \rightarrow$

$\mathrm{Cu}_{0.667} \mathrm{Al}_{0.333}(\mathrm{OH})_{2}\left(\mathrm{SO}_{4}\right)_{0.1665}$

Precipitation of $\mathrm{Cu}$ and $\mathrm{Al}$ nitrates in the presence of sodium nitrate:

$0.667 \mathrm{Cu}\left(\mathrm{NO}_{3}\right)_{2}+0.333 \mathrm{Al}\left(\mathrm{NO}_{3}\right)_{3}+\mathrm{NaNO}_{3}+\mathrm{NaOH} \rightarrow$ $\mathrm{Cu}_{0.667} \mathrm{Al}_{0.333}(\mathrm{OH})_{2}\left(\mathrm{NO}_{3}\right)_{0.333}$

Precipitation of $\mathrm{Cu}$ and $\mathrm{Al}$ nitrates in the presence of sodium carbonate:

$0.667 \mathrm{Cu}\left(\mathrm{NO}_{3}\right)_{2}+0.333 \mathrm{Al}\left(\mathrm{NO}_{3}\right)_{3}+\mathrm{Na}_{2} \mathrm{CO}_{3}+\mathrm{NaOH} \rightarrow$
$\mathrm{Cu}_{0.667} \mathrm{Al}_{0.333}(\mathrm{OH})_{2}\left(\mathrm{CO}_{3}\right)_{0.1665}$

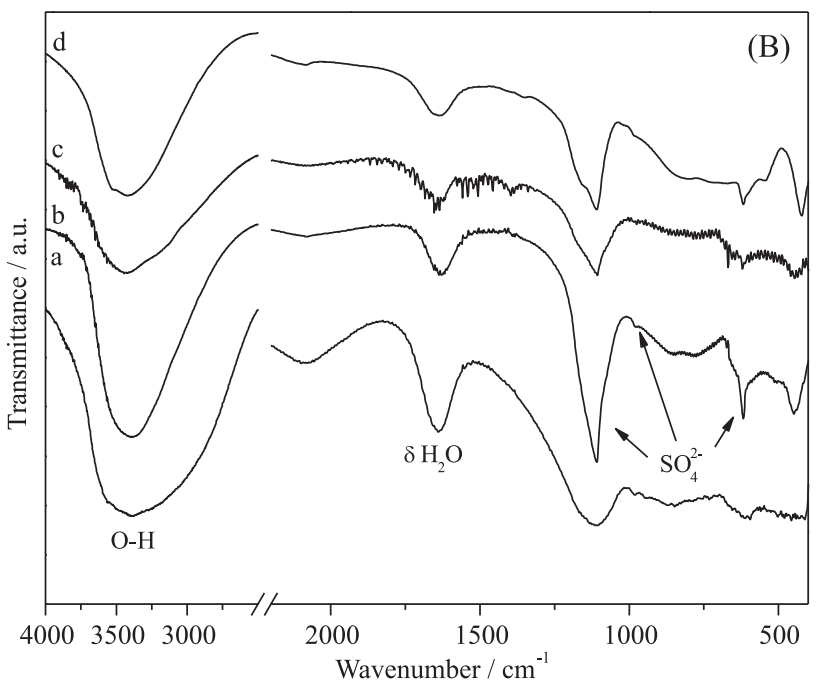

Figure 6. (A) XRD patterns and (B) FTIR spectra of (a) $\mathrm{Cu}_{2} \mathrm{Al}-\mathrm{SO}_{4} / \mathrm{Na}$ and (b) after exchange with $\mathrm{NH}_{4}$, of (c) $\mathrm{Cu}_{2} \mathrm{Al}_{-}-\mathrm{SO}_{4} / \mathrm{NH}_{4}$ and (d) after exchange with Na. 

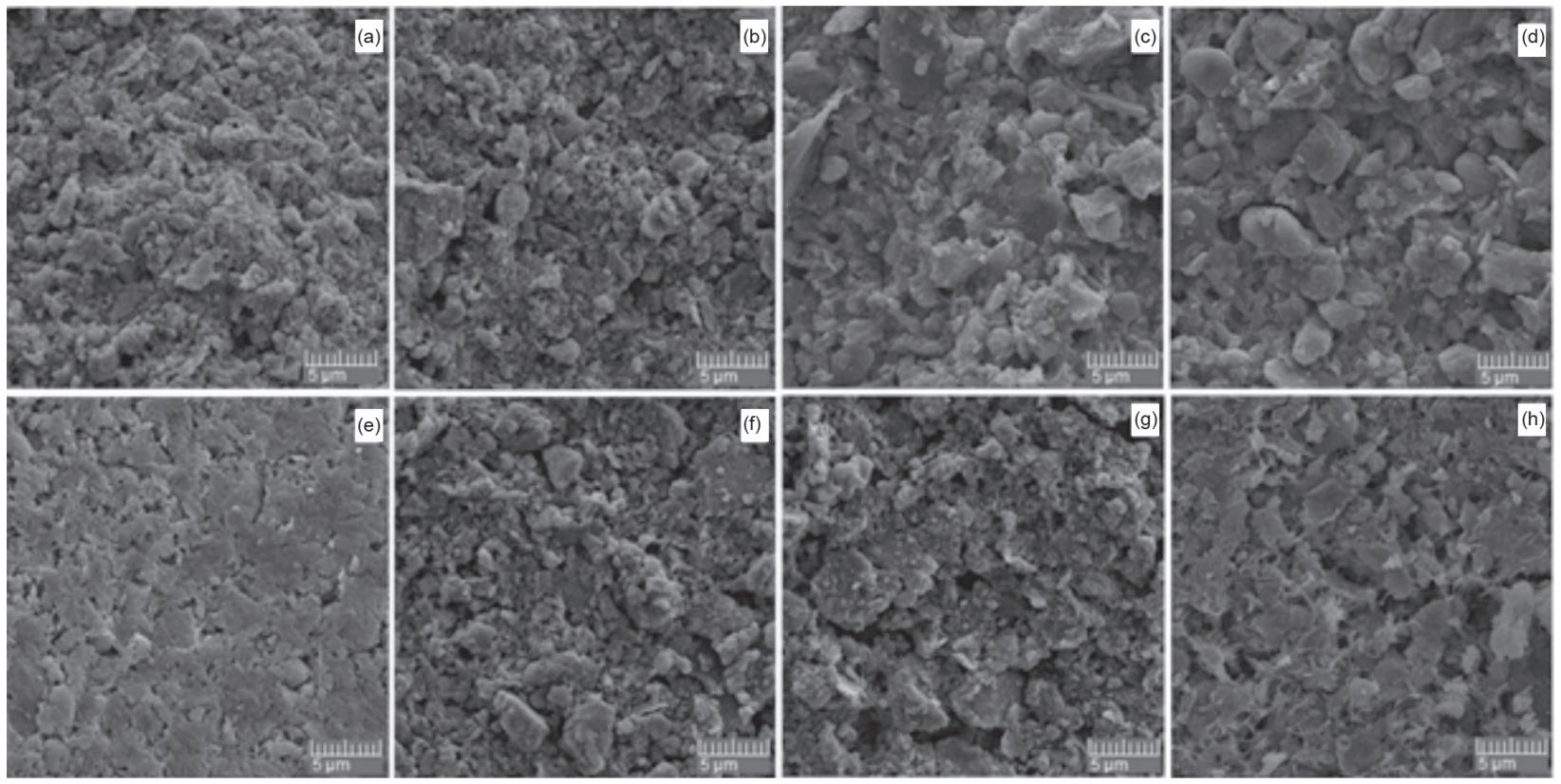

Figure 7. SEM images of $\mathrm{Cu}_{2} \mathrm{Al}-\mathrm{SO}_{4} / \mathrm{Li}$ after exchange with (a) $\mathrm{Na}$ and (b) $\mathrm{K}$; of $\mathrm{Cu}_{2} \mathrm{Al}_{-}-\mathrm{SO}_{4} / \mathrm{Na}$ after exchange with (c) $\mathrm{Li}$, (d) $\mathrm{K}$ and (e) $\mathrm{NH}$; of Cu $\mathrm{SO}_{4} / \mathrm{K}$ after exchange with (f) $\mathrm{Li}$ and $(\mathrm{g}) \mathrm{Na}$; and of $\mathrm{Cu}_{2} \mathrm{Al}-\mathrm{SO}_{4} / \mathrm{NH}_{4}$ after exchange with (h) Na.

\section{Exchange reactions}

Using $\mathrm{Li}_{2} \mathrm{SO}_{4}, \mathrm{~K}_{2} \mathrm{SO}_{4}, \mathrm{Na}_{2} \mathrm{SO}_{4},\left(\mathrm{NH}_{4}\right)_{2} \mathrm{SO}_{4}\left(\mathrm{~B}=\mathrm{Li}^{+}\right.$, $\mathrm{Na}^{+}, \mathrm{K}^{+}, \mathrm{NH}_{4}^{+}$):

$\mathrm{Cu}_{0.667} \mathrm{Al}_{0.333}(\mathrm{OH})_{2}\left(\mathrm{SO}_{4}\right)_{0.1665}+\mathrm{B}_{2} \mathrm{SO}_{4} \rightarrow$ no apparent reaction

$\mathrm{Cu}_{0.667} \mathrm{Al}_{0.333}(\mathrm{OH})_{2}\left(\mathrm{NO}_{3}\right)_{0.333}+\mathrm{B}_{2} \mathrm{SO}_{4} \rightarrow$ no apparent reaction

$\mathrm{Cu}_{0.667} \mathrm{Al}_{0.333}(\mathrm{OH})_{2}\left(\mathrm{CO}_{3}\right)_{0.1665}+\mathrm{B}_{2} \mathrm{SO}_{4} \rightarrow$ no apparent reaction

Using $\mathrm{Cu}_{2} \mathrm{Al}-\mathrm{SO}_{4} / \mathrm{Li}$ phase and different alkali metals or ammonium sulfate salts:

$$
\begin{aligned}
& \mathrm{Cu}_{0.667} \mathrm{Al}_{0.333}(\mathrm{OH})_{2}\left(\mathrm{SO}_{4}\right)_{0.211} \mathrm{Li}_{0.111}+\mathrm{Na}_{2} \mathrm{SO}_{4} \rightarrow \\
& \mathrm{Cu}_{0.667} \mathrm{Al}_{0.333}(\mathrm{OH})_{2}\left(\mathrm{SO}_{4}\right)_{0.211-\mathrm{y}}\left(\mathrm{CO}_{3}\right)_{\mathrm{y}} \mathrm{Li}_{0.111-\mathrm{x}} \mathrm{Na}_{\mathrm{x}} \\
& \mathrm{Cu}_{0.667} \mathrm{Al}_{0.333}(\mathrm{OH})_{2}\left(\mathrm{SO}_{4}\right)_{0.211} \mathrm{Li}_{0.111}+\mathrm{K}_{2} \mathrm{SO}_{4} \rightarrow \\
& \mathrm{Cu}_{0.667} \mathrm{Al}_{0.333}(\mathrm{OH})_{2}\left(\mathrm{SO}_{4}\right)_{0.211-\mathrm{y}}\left(\mathrm{CO}_{3}\right)_{\mathrm{y}} \mathrm{Li}_{0.111-\mathrm{x}} \mathrm{K}_{\mathrm{x}} \\
& \mathrm{Cu}_{0.667} \mathrm{Al}_{0.333}(\mathrm{OH})_{2}\left(\mathrm{SO}_{4}\right)_{0.211} \mathrm{Li}_{0.111}+\left(\mathrm{NH}_{4}\right)_{2} \mathrm{SO}_{4} \rightarrow \\
& \mathrm{Cu}_{0.667} \mathrm{Al}_{0.333}(\mathrm{OH})_{2}\left(\mathrm{SO}_{4}\right)_{0.211-\mathrm{y}}\left(\mathrm{CO}_{3}\right)_{\mathrm{y}} \mathrm{Li}_{0.111-\mathrm{x}}\left(\mathrm{NH}_{4}\right)_{\mathrm{x}}
\end{aligned}
$$

After extending the reaction time:

$$
\begin{aligned}
& \mathrm{Cu}_{0.667} \mathrm{Al}_{0.333}(\mathrm{OH})_{2}\left(\mathrm{SO}_{4}\right)_{0.211} \mathrm{Li}_{0.111}+\mathrm{B}_{2} \mathrm{SO}_{4} \rightarrow \\
& \mathrm{Cu}_{0.667} \mathrm{Al}_{0.333}(\mathrm{OH})_{2}\left(\mathrm{SO}_{4}\right)_{0.1665}\left(\mathrm{~B}=\mathrm{Na}^{+}, \mathrm{K}^{+}, \mathrm{NH}_{4}^{+}\right)
\end{aligned}
$$

Using $\mathrm{Cu}_{2} \mathrm{Al}-\mathrm{SO}_{4} / \mathrm{Na}$ phase and different alkali metals or ammonium sulfate salts:

$$
\begin{aligned}
& \mathrm{Cu}_{0.667} \mathrm{Al}_{0.333}(\mathrm{OH})_{2}\left(\mathrm{SO}_{4}\right)_{0.211} \mathrm{Na}_{0.111}+\mathrm{Li}_{2} \mathrm{SO}_{4} \rightarrow \\
& \mathrm{Cu}_{0.667} \mathrm{Al}_{0.333}(\mathrm{OH})_{2}\left(\mathrm{SO}_{4}\right)_{0.211} \mathrm{Na}_{0.111-\mathrm{x}} \mathrm{Li}_{\mathrm{x}} \rightarrow \\
& \mathrm{Cu}_{0.667} \mathrm{Al}_{0.333}(\mathrm{OH})_{2}\left(\mathrm{SO}_{4}\right)_{0.211} \mathrm{Li}_{0.111} \\
& \mathrm{Cu}_{0.667} \mathrm{Al}_{0.333}(\mathrm{OH})_{2}\left(\mathrm{SO}_{4}\right)_{0.211} \mathrm{Na}_{0.111}+\mathrm{K}_{2} \mathrm{SO}_{4} \rightarrow \\
& \mathrm{Cu}_{0.667} \mathrm{Al}_{0.333}(\mathrm{OH})_{2}\left(\mathrm{SO}_{4}\right)_{0.211} \mathrm{Na}_{0.111-\mathrm{x}} \mathrm{K}_{\mathrm{x}} \rightarrow \\
& \mathrm{Cu}_{0.667} \mathrm{Al}_{0.333}(\mathrm{OH})_{2}\left(\mathrm{SO}_{4}\right)_{0.211} \mathrm{~K}_{0.111} \\
& \mathrm{Cu}_{0.667} \mathrm{Al}_{0.333}(\mathrm{OH})_{2}\left(\mathrm{SO}_{4}\right)_{0.211} \mathrm{Na}_{0.111}+\left(\mathrm{NH}_{4}\right)_{2} \mathrm{SO}_{4} \rightarrow \\
& \mathrm{Cu}_{0.667} \mathrm{Al}_{0.333}(\mathrm{OH})_{2}\left(\mathrm{SO}_{4}\right)_{0.211} \mathrm{Na}_{0.111-\mathrm{x}}\left(\mathrm{NH}_{4}\right)_{\mathrm{x}} \rightarrow \\
& \mathrm{Cu}_{0.667} \mathrm{Al}_{0.333}(\mathrm{OH})_{2}\left(\mathrm{SO}_{4}\right)_{0.211}\left(\mathrm{NH}_{4}\right)_{0.111}
\end{aligned}
$$

Only in the case of the system $\mathrm{Cu}_{2} \mathrm{Al}-\mathrm{SO}_{4} / \mathrm{Na}$, real cation exchange reactions occurred. In the schematic representations of both possible structures adopted for $\mathrm{Cu}_{0.667} \mathrm{Al}_{0.333}(\mathrm{OH})_{2}\left(\mathrm{SO}_{4}\right)_{0.211} \mathrm{Na}_{0.111}$ or shigaite-like structure, and hydrated $\mathrm{Cu}_{0.667} \mathrm{Al}_{0.333}(\mathrm{OH})_{2}\left(\mathrm{SO}_{4}\right)_{0.1665} \cdot \mathrm{nH}_{2} \mathrm{O}$ (Figure 8), it is difficult to detect the differences by the traditional instrumental techniques used in materials science, especially due to the very close basal distances, low concentration of alkali metals, and slight increase of sulfate amount in the first in comparison to the second.

It is common to detect alkali metal cations in the analysis when the sample is not properly washed, especially when the precipitate is submitted to filtration or centrifugation without dispersing the solid after each centrifugation step. 

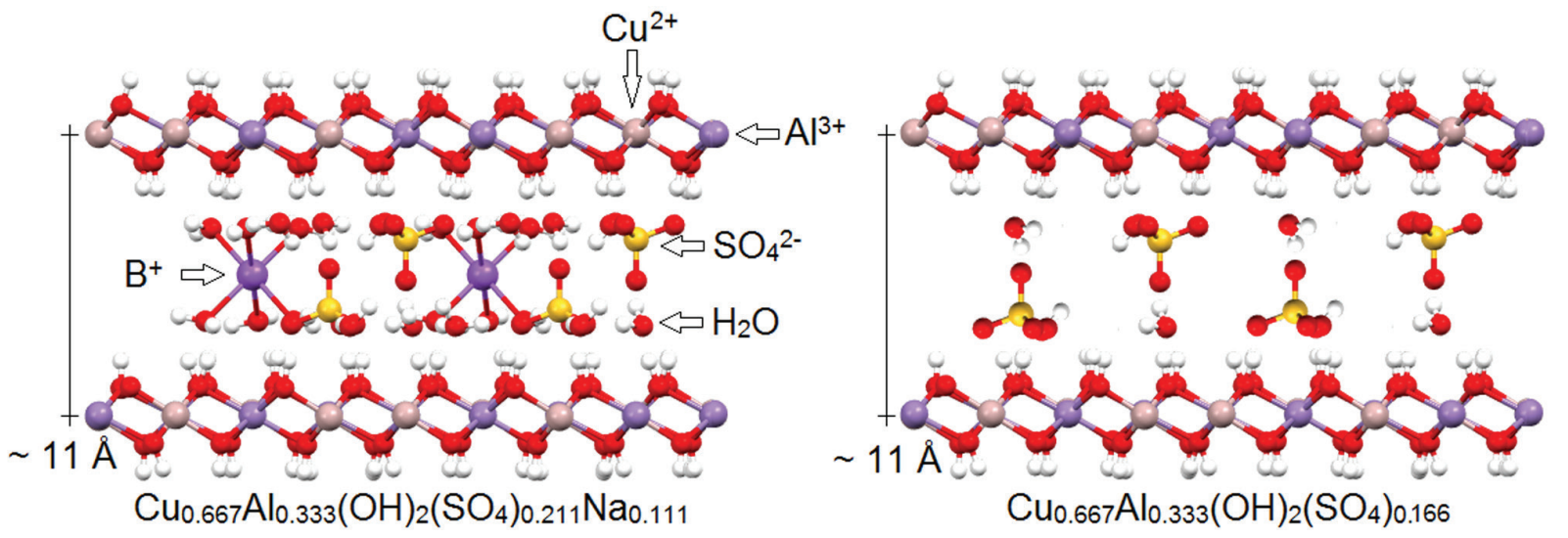

Figure 8. Schematic representation of both possible structures adopted for $\mathrm{Cu}_{0.667} \mathrm{Al}_{0.333}(\mathrm{OH})_{2}\left(\mathrm{SO}_{4}\right)_{0.211} \mathrm{Na}_{0.111}$ and hydrated Cu $\mathrm{Cu}_{0.667} \mathrm{Al}_{0.333}(\mathrm{OH})_{2}\left(\mathrm{SO}_{4}\right)_{0.1665}$.

The best technique to differentiate the two structures is quantitative analysis, especially via ICP OES.

\section{Conclusions}

Layered double hydroxides of $\mathrm{Cu}: \mathrm{Al}$ in the molar ratio of 2:1 intercalated with sulfate, nitrate and carbonate were successfully synthesized by co-precipitation at $50{ }^{\circ} \mathrm{C}$, followed by ripening at $90{ }^{\circ} \mathrm{C}$. To investigate the quality of the structures of the precipitated materials, an optimization step was included where solid were removed during the titration process. After identifying the optimized pHs, new synthesis were performed for all compositions. The compounds synthesized with sulfate in the presence of $\mathrm{Na}^{+}$and $\mathrm{K}^{+}$had the greatest basal distances (around $11 \AA$ ) , consistent with the intercalation of sulfate anions and hydrated cations. The same did not occur with the compound synthesized with lithium, which had a basal distance around of $8.9 \AA$, possibly due to the absence of coordinated molecules in the interlayer space and absence of the Ostwald ripening process.

In the case of the samples synthesized with $\mathrm{NH}_{4}{ }^{+}$, the basal distances varied from 8.2 to $10.7 \AA$, consistent with the dehydrated and hydrated sulfate, while the samples synthesized with carbonate and nitrate presented basal distances consistent with the intercalation of the respective anions.

SEM images indicated typical LDH morphology and the presence of micrometric or submicrometric particles, while FTIR spectra were similar to those of other LDHs and showed bands consistent with intercalated anions.

ICP OES and thermogravimetric analysis indicated that the phases $\mathrm{Cu}_{2} \mathrm{Al}-\mathrm{SO}_{4} / \mathrm{Li}$ and $\mathrm{Cu}_{2} \mathrm{Al}-\mathrm{SO}_{4} / \mathrm{Na}$ had the expected composition $\left[\mathrm{Cu}_{6} \mathrm{Al}_{3}(\mathrm{OH})_{18}\right]\left[\mathrm{B}\left(\mathrm{H}_{2} \mathrm{O}\right)_{6}\left(\mathrm{SO}_{4}\right)_{2}\right] \cdot 6 \mathrm{H}_{2} \mathrm{O}$ ( $\mathrm{B}=\mathrm{Li}^{+}, \mathrm{Na}^{+}$), while the phases $\mathrm{Cu}_{2} \mathrm{Al}-\mathrm{SO}_{4} / \mathrm{K}$, in spite of having a small amount of alkali metals and the basal distance expected for the phases containing sulfate/ alkali metals or ammonium, had composition close to $\mathrm{Cu}_{0.667} \mathrm{Al}_{0.333}(\mathrm{OH})_{2}\left(\mathrm{SO}_{4}\right)_{0.1665}$, where sulfate was hydrated as in hydrowoodwardite. In the case of $\mathrm{Cu}_{2} \mathrm{Al}-\mathrm{SO}_{4} / \mathrm{NH}_{4}$, sulfate was dehydrated as in woodwardite.

All the samples were submitted to exchange reactions using $\mathrm{B}_{2} \mathrm{SO}_{4}\left(\mathrm{~B}=\mathrm{Li}^{+}, \mathrm{Na}^{+}, \mathrm{K}^{+}, \mathrm{NH}_{4}^{+}\right)$solutions in an attempt to replace previously intercalated cations or incorporated cations, without removing intercalated sulfate. The XRD patterns and FTIR spectra were consistent with the expected intercalated species and SEM images indicated submicrometric platelet-like particles, typical of LDHs.

According to ICP OES analysis, $\mathrm{Cu}_{2} \mathrm{Al}-\mathrm{SO}_{4} / \mathrm{Li}$ had lower amounts of sulfate and lithium after the exchange reactions, while in $\mathrm{Cu}_{2} \mathrm{Al}-\mathrm{SO}_{4} / \mathrm{Na}$ the sodium cations were almost totally replaced with lithium, potassium and ammonium, without removing the intercalated sulfate. Phases containing nitrate or carbonate could not be analyzed since the exchanged with sulfate/alkali metals or ammonium lead to the drastic reduction of crystallinity.

In spite of this contribution, structural aspects and properties of $\mathrm{Cu} / \mathrm{Al}-\mathrm{SO}_{4} \mathrm{LDH}$ still need to be further investigated.

\section{Acknowledgments}

This study was financed in part by the Office to Coordinate Improvement of University Personnel (CAPES, finance code 001), National Council for Scientific and Technological Development (CNPq, projects 400117/20169 and 300988/2019-2) and the Financier of Studies and Projects (FINEP). A. R. S. thanks CAPES for the PhD scholarship. We also acknowledge Center for Electron Microscopy of Federal University of Paraná (CME-UFPR) for the SEM and Prof Marcos Rogério Mafra (DEQ-UFPR) for the TGA analyses. 


\section{References}

1. Constantino, V. R. L.; Pinnavaia, T. J.; Inorg. Chem. 1995, 34, 883.

2. Wang, Q.; O’Hare, D.; Chem. Rev. 2012, 112, 4124.

3. Chubar, N.; Gilmour, R.; Gerda, V.; Mičušík, M.; Omastova, M.; Heister, K.; Man, P.; Fraissard, J.; Zaitsev, V.; Adv. Colloid Interface Sci. 2017, 245, 62.

4. Chen, Y.; Jing, C.; Zhang, X.; Jiang, D.; Liu, X.; Dong, B.; Feng, L.; Li, S.; Zhang, Y.; J. Colloid Interface Sci. 2019, 548, 100.

5. Cavani, F.; Trifiro, F.; Vaccari, A.; Catal. Today 1991, 11, 173.

6. Crepaldi, E. L.; Valim, J. B.; Quim. Nova 1998, 21, 300.

7. Chitrakar, R.; Sonoda, A.; Makita, Y.; Hirotsu, T.; Sep. Purif. Technol. 2011, 80, 652.

8. Miyata, S.; Clays Clay Miner. 1983, 31, 305.

9. Meyn, M.; Beneke, K.; Lagaly, G.; Inorg. Chem. 1990, $29,5201$.

10. Bravo-Suárez, J. J.; Páez-Mozo, E. A.; Oyama, S. T.; Quim. Nova 2004, 27, 601.

11. Chang, Z.; Evans, D. G.; Duan, X.; Vial, C.; Ghanbaja, J.; Prevot, V.; de Roy, M.; Forano, C.; J. Solid State Chem. 2005, $178,2766$.

12. Basu, D.; Das, A.; Stöckelhuber, K. W.; Wagenknecht, U.; Heinrich, G.; Prog. Polym. Sci. 2014, 39, 594.

13. Sotiles, A. R.; Baika, L. M.; Grassi, M. T.; Wypych, F.; J. Am. Chem. Soc. 2019, 141, 531.

14. Rodgers, K. A.; Chisholm, J. E.; Davis, R. J.; Nelson, C. S.; Mineral. Mag. 1977, 41, 389.

15. Cooper, M. A.; Hawthorne, F. C.; Can. Mineral. 1996, 34, 91.

16. Mills, S. J.; Christy, A. G.; Génin, J. M. R.; Kameda, T.; Colombo, F.; Mineral. Mag. 2012, 76, 1289.

17. Sotiles, A. R.; Gomez, N. A. G.; dos Santos, M. P.; Grassi, M. T.; Wypych, F.; Appl. Clay Sci. 2019, 181, 105217.

18. Gomez, N. A. G.; Wypych, F.; J. Polym. Res. 2019, 26, 203.

19. Zhang, N.; Zhang, L.; Sun, D.; Langmuir 2015, 31, 4619.

20. Nakagaki, S.; Castro, K. A. D. F.; Ucoski, G. M.; Halma, M.; Prévot, V.; Forano, C.; Wypych, F.; J. Braz. Chem. Soc. 2014, 25, 2329.

21. Castro, K. A. D. F.; Halma, M.; Machado, G. S.; Ricci, G. P.; Ucoski, G. M.; Ciuffi, K. J.; Nakagaki, S.; J. Braz. Chem. Soc. 2010, 21, 1329.

22. Zhou, H.; Jiang, Z.; Wei, S.; Appl. Clay Sci. 2018, 153, 29.

23. Wang, X.; Wu, P.; Lu, Y.; Huang, Z.; Zhu, N.; Lin, C.; Dang, Z.; Sep. Purif. Technol. 2014, 132, 195.

24. Wang, H.; Zhang, Z.; Jing, M.; Tang, S.; Wu, Y.; Liu, W.; Appl. Clay Sci. 2020, 186, 105433.

25. Bini, M.; Monteforte, F.; Quinzeni, I.; Friuli, V.; Maggi, L.; Bruni, G.; J. Solid State Chem. 2019, 272, 131.

26. Yasaei, M.; Khakbiz, M.; Zamanian, A.; Ghasemi, E.; Mater. Sci. Eng., C 2019, 103, 109816.

27. Yasaei, M.; Khakbiz, M.; Ghasemi, E.; Zamania, A.; Appl. Surf. Sci. 2019, 467-468, 782.
28. Gómez, N. A. G.; Silva, G. M.; Wilhelm, H. M.; Wypych, F.; J. Braz. Chem. Soc. 2020, 31, 971.

29. Jaerger, S.; Wypych, F.; J. Appl. Polym. Sci. 2019, 48737.

30. Suzuki, J.; Ito, M.; Sugiura, T.; J. Jpn. Assoc. Mineral., Petrol. Econ. Geol. 1976, 71, 183.

31. Sarp, H.; Perroud, P.; N. Jb. Miner. Mh., Jg. 1991, 11, 481.

32. Cuchet, S.; Schweiz. Mineral. Petrogr. Mitt. 1995, 75, 283.

33. Frost, R. L.; Keeffe, E. C.; Spectrochim. Acta, Part A 2011, 81, 111.

34. Mills, S. J.; Christy, A. G.; Schnyder, C.; Favreau, G.; Price, J. R.; Mineral. Mag. 2014, 78, 1527.

35. Mills, S. J.; Christy, A. G.; Colombo, F.; Price, J. R.; Mineral. Mag. 2015, 79, 321.

36. Mills, S. J.; Christy, A. G.; Favreaud, G.; Galea-Cloluse, V.; Acta Crystallogr., Sect. B 2017, 73, 950.

37. Ventruti, G.; Mugnaioli, E.; Capitani, G.; Scordari, F.; Pinto, D.; Lausi, A.; Phys. Chem. Miner. 2015, 42, 651.

38. Boclair, J. W.; Braterman, P. S.; Chem. Mater. 1998, 10, 2050.

39. Layrac, G.; Harrisson, S.; Destarac, M.; Gérardin, C.; Tichit, D.; Appl. Clay Sci. 2020, 193, 105673.

40. Fan, G.; Li, F.; Evans, D. G.; Duan, X.; Chem. Soc. Rev. 2014, 43, 7040 .

41. Yan, K.; Liu, Y.; Lu, Y.; Chai, J.; Sun, L.; Catal. Sci. Technol. 2017, 7, 1622.

42. Li, J.; Zhang, S.; Chen, Y.; Liu, T.; Liu, C.; Zhang, X.; Yi, M.; Chu, Z.; Han, X.; RSC Adv. 2017, 7, 29051.

43. Britto, S.; Radha, A.; Ravishankar, N.; Kamath, P. V.; Solid State Sci. 2007, 9, 279.

44. Sotiles, A. R.; Wypych, F.; Chem. Commun. 2019, 55, 7824.

45. Krivovichev, S. V.; Yakovenchuk, V. N.; Zolotarev, A. A.; Ivanyuk, G. N.; Pakhomovski, Y. A.; Chimia 2010, 64, 730.

46. Merlino, S.; Orlandi, P.; Am. Mineral. 2001, 86, 1293.

47. Zhu, Y.; Rong, J.; Zhang, T.; Xu, J.; Dai, Y.; Qiu, F.; ACS Appl. Nano Mater. 2018, 1, 284.

48. Nickel, E.; Mineral. Mag. 1976, 43, 644.

49. Witzke, T.; Neues Jahrb. Mineral., Monatsh. 1999, 2, 75.

50. Khaldi, M.; de Roy, A.; Chaouch, M.; Besse J. P.; J. Solid State Chem. 1997, 130, 66.

51. Frost, R. L.; Kloprogge, J. T.; Spectrochim. Acta, Part A 1999, $55,2195$.

52. Frost, R. L.; Weier, M. L.; Clissold, M. E.; Williams, P. A.; Spectrochim. Acta, Part A 2003, 59, 3313.

53. Badreddine, M.; Khaldi, M.; Legrouri, A.; Barroug, A.; Chaouch, M.; de Roy, A.; Besse, J. P.; Mater. Chem. Phys. 1998, $52,235$.

54. Badreddine, M.; Legrouri, A.; Barroug, A.; de Roy, A.; Besse, J. P.; Mater. Lett. 1999, 38, 391.

55. Mahjoubi, F. Z.; Khalid, A.; Abdennouri, M.; Barka, N.; J. Taibah Univ. Sci. 2017, 11, 90.

56. Faramawy, S.; Zaki, T.; Sakr, A. A. E.; Saber, O.; Aboul-Gheit, A. K.; Hassan, S. A.; J. Nat. Gas Sci. Eng. 2018, 54, 72. 
57. Hager, S. L.; Leverett, P.; Williams, P. A.; Can. Mineral. 2009, 47, 635.

58. Park, Y.; Kuroda, K.; Kato, C.; Solid State Ionics 1990, $42,197$.

59. Jayanthi, K.; Kamath, P. V.; Periyasamy, G.; Eur. J. Inorg. Chem. 2017, 3675.

60. Radha, S.; Antonyraj, C. A.; Kamath, P. V.; Kannan, S.; Z. Anorg. Allg. Chem. 2010, 636, 2658.

61. Sotiles, A. R.; Gomez, N. A. G.; da Silva, S. C.; Wypych, F.; J. Braz. Chem. Soc. 2019, 30, 1807.

62. Huminicki, D. M. C.; Hawthorne, F. C.; Grice, J. D.; Roberts, A. C.; Jambor, J. L.; Mineral. Rec. 2003, 34, 155.

63. Wachowiak, J.; Pieczka, A.; Mineral. Mag. 2016, 80, 277.

64. Zamarreño, I.; Plana, F.; Vazquez, A.; Clague, D. A.; Am. Mineral. 1989, 74, 1054.

65. Kang, H.; Leoni, M.; He, H.; Huang, G.; Yang, X.; Eur. J. Inorg. Chem. 2012, 3859.
66. Berner, S.; Araya, O.; Govan, J.; Palza, H.; J. Ind. Eng. Chem. 2018, 59, 134.

67. Kloprogge, J. T.; Wharton, D.; Hickey, L.; Frost, R. L.; Am. Mineral. 2002, 87, 623.

68. Kloprogge, J. T.; Hickey, L.; Frost, R. L.; Mater. Chem. Phys. 2005, 89, 99.

69. Liu, J.; Song, J.; Xiao, H.; Zhang, L.; Qin, Y.; Liu, D.; Hou, W.; Du, N.; Powder Technol. 2014, 253, 41.

70. Karami, Z.; Jouyandeh, M.; Hamad, S. M.; Ganjali, M. R.; Aghazadeh, M.; Torre, L.; Puglia, D.; Saeb, M. R.; Prog. Org. Coat. 2019, 136, 105278.

71. Kameda, T.; Fubasami, Y.; Yoshioka, T.; J. Therm. Anal. Calorim. 2012, 110, 641.

Submitted: April 4, 2020 Published online: August 14, 2020 